\title{
Influence of sulfide, chloride and dissolved organic matter on mercury adsorption by activated carbon in aqueous system
}

\author{
Chi Chen, Yu Ting, Boon-Lek Ch'ng and Hsing-Cheng Hsi ${ }^{*}$ (D)
}

\begin{abstract}
Using activated carbon (AC) as thin layer capping to reduce mercury $(\mathrm{Hg})$ released from contaminated sediment is a feasible and durable remediation approach. However, several aqueous factors could greatly affect the $\mathrm{Hg}$ fate in the aquatic system. This study thus intends to clarify the influences on $\mathrm{Hg}$ adsorption by AC with the presence of sulfide, dissolved organic matter (DOM), and chloride. The lab-scale batch experiments were divided into two parts, including understanding (1) AC adsorption performance and (2) Hg distribution in different phases by operational definition method. Results showed that the $\mathrm{Hg}$ adsorption rate by AC was various with the presence of sulfide, chloride, and DOM (from fast to slow). $\mathrm{Hg}$ adsorption might be directly bonded to $\mathrm{AC}$ with $\mathrm{Hg}-\mathrm{Cl}$ and $\mathrm{Hg}-\mathrm{DOM}$ complexes and the rate was mainly controlled by intraparticle diffusion. In contrast, "Hg + sulfide" result was better described by pseudo-second order kinetics. The Hg removal efficiency was $92-95 \%$ with the presence of 0-400 mM chloride and approximately $65-75 \%$ in the "Hg + sulfide" condition. Among the removed Hg, 24-29\% was formed into aqueous-phase particles and about 30\% $\mathrm{Hg}$ was adsorbed on AC with 2-20 $\mu \mathrm{M}$ sulfide. Increasing DOM concentration resulted in more dissolved $\mathrm{Hg}$. The proportion of dissolved $\mathrm{Hg}$ increased $31 \%$ by increasing DOM concentration from 0.25 to $20 \mathrm{mg} \mathrm{CL}^{-1}$. Simultaneously, the proportion of adsorbed $\mathrm{Hg}$ by AC decreased by $47 \%$. Overall, the presence of chloride increases the $\mathrm{Hg}$ adsorption by AC. In contrast, the presence of sulfide and DOM causes a negative effect on AC adsorption.
\end{abstract}

Keywords: Mercury, Activated carbon, Chloride, Sulfide, Dissolved organic matter

\section{Introduction}

Mercury $(\mathrm{Hg})$ has been known as one of the most toxic heavy metals to human beings and living organisms [1-3]. Despite the decreasing industrial use of $\mathrm{Hg}$ in the past recent years, human activities including fossil fuel combustions, gold-mining, and manufacturing industries have contributed to the increased $\mathrm{Hg}$ levels in the atmosphere and aquatic environments [4]. The released $\mathrm{Hg}$ could ultimately transport to aquatic system and accumulate in sediment through wet or dry deposition. Thus, the formation and bioaccumulation of methylmercury $(\mathrm{MeHg})$ formed from inorganic $\mathrm{Hg}$ under reducing conditions in sediment could put a serious threat to aquatic ecosystems $[5,6]$.

\footnotetext{
* Correspondence: hchsi@ntu.edu.tw

Graduate Institute of Environmental Engineering, National Taiwan University, Taipei 10617, Taiwan
}

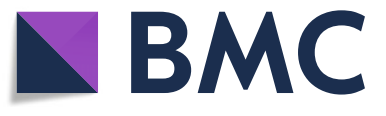

( ) The Author(s). 2020 Open Access This article is licensed under a Creative Commons Attribution 4.0 International License, which permits use, sharing, adaptation, distribution and reproduction in any medium or format, as long as you give

appropriate credit to the original author(s) and the source, provide a link to the Creative Commons licence, and indicate if changes were made. The images or other third party material in this article are included in the article's Creative Commons licence, unless indicated otherwise in a credit line to the material. If material is not included in the article's Creative Commons licence and your intended use is not permitted by statutory regulation or exceeds the permitted use, you will need to obtain permission directly from the copyright holder. To view a copy of this licence, visit http://creativecommons.org/licenses/by/4.0/. contaminated sediment, as the traditional approaches could not achieve risk reduction goals for human health and ecosystem protection and may even cause secondary pollution [7-9]. For example, dredging followed by ex-situ approaches has been typically used because of its longterm effectiveness and relatively short remediation time [10]. Nevertheless, dredging could be very costly and results into remobilization of contaminants [11]. In-situ thin-layer capping, which involves the use of chemically reactive materials that reduce the mobility, toxicity, and bioavailability of the contaminant, subsequently reducing ecological and human health risk, has been developed as a novel remediation of contaminated sediment $[7,12]$. The use of activated adsorbents as capping materials has turned out to be a less expensive and high potential 
approach due to the ability to adsorb newly deposited contaminants. In previous studies of our research group, activated carbon (AC) was reported to successfully inhibit inorganic $\mathrm{Hg}$ and $\mathrm{MeHg}$ release into the overlying water in a lab-scale microcosm experiment $[13,14]$. AC has been widely known as an effective adsorbent to remove $\mathrm{Hg}$ in recent years [15-19].

Several environmental factors, namely sulfide, chloride, and dissolved organic matter (DOM) could significantly affect the $\mathrm{Hg}$ fate in aquatic systems. The sulfide minerals in sediment are mainly the products of oxidizing organic matters by sulfate-reducing bacteria [20]. Sulfide has high affinity for $\mathrm{Hg}$ and can form $\mathrm{HgS}$ particles; the forming of $\mathrm{HgS}_{(\mathrm{s})}$ structure may inhibit $\mathrm{Hg}$ from being methylated and being transported $[21-23] . \mathrm{Hg}^{2+}$ concentrations are quite low as compared to sulfide concentration in aquatic ecosystems. Therefore, sulfides could control $\mathrm{Hg}$ speciation significantly and play an important role for stabilizing $\mathrm{Hg}$ in sediment [24].

Natural DOM in the stream water is typically at the range of 1 to $5 \mathrm{mg} \mathrm{C} \mathrm{L} \mathrm{L}^{-1}$, while in some high-organic soils or vegetated environments, DOM may have concentrations up to 20 or $50 \mathrm{mg} \mathrm{C} \mathrm{L}^{-1}$ [25]. DOM is shown to hinder the aggregation of $\mathrm{HgS}$ particles by forming coordinate covalent bonds between functional groups on the organic molecules and atoms on the surface of the particles [26]. Importantly, $\mathrm{Hg}$ interacted with DOM increased the methylating rate in comparison to $\mathrm{Hg}^{2+}$; moreover, the $\beta$ - $\mathrm{HgS}$ nanoparticles formed by $\mathrm{Hg}$ mixed with sulfide and DOM have a higher availability than $\beta-\mathrm{HgS}$ microparticles for bacterial methylation [26]. Recent studies have also shown that thiol functional groups are the major binding sites which mainly increases solubility, mobility and toxicity of $\mathrm{Hg}[27,28]$.

The oxidation and reduction of $\mathrm{Hg}$ in the presence of chloride ion $\left(\mathrm{Cl}^{-}\right)$have also been studied mainly in oxic environments. The $\mathrm{Hg}-\mathrm{Cl}$ complexes were regarded as nonadsorption $\mathrm{Hg}$ speciation in previous studies. $\mathrm{Hg}-\mathrm{Cl} \mathrm{com}-$ plexes were also reported to inhibit $\mathrm{Hg}$ reduction to gaseous $\mathrm{Hg}$ [29]. Lee et al. [29] also reported that the increase of $\mathrm{Cl}^{-}$concentration inhibited $\mathrm{Hg}^{2+}$ reduction rate as the rate constant ranged from 0.14 to $1.7 \mathrm{~h}^{-1}$ in the presence of $\mathrm{Cl}^{-}$as compared to $2.4 \mathrm{~h}^{-1}$ in the absence of $\mathrm{Cl}^{-}$. Consequently, the health risk of organisms in the aquatic ecosystem is dependent on $\mathrm{Hg}$ chemical speciation and the phase of $\mathrm{Hg}$ rather than total $\mathrm{Hg}$ concentrations in the sediments.

Past studies showed that sulfide, DOM, and chloride ions could stabilize $\mathrm{Hg}$ in aquatic system. To further inference, sulfide, DOM, and chloride might inhibit $\mathrm{Hg}$ adsorption by $\mathrm{AC}$ and influence the $\mathrm{Hg}$ partitioning within various phases (i.e., aqueous, $\mathrm{AC}$, and precipitation phases) that are still needed to be better comprehended. Therefore, in this study, batch experiments were conducted to gain further knowledge on the behavior of $\mathrm{Hg}$ adsorption by AC affected by sulfide, DOM, and chloride at various concentrations. The results obtained from this work could help clarifying the $\mathrm{Hg}$ adsorption mechanism by AC under the presence of essential elements in natural habitat, especially focusing on the impacts of sulfide, DOM, and chloride, and further help justifying whether thin layer capping can be applied to the aquatic system with the presence of these compounds at various concentrations.

\section{Materials and methods}

Lab-scale batch experiments were conducted to better understand the influences of sulfide, chloride, and DOM concentrations on $\mathrm{Hg}$ adsorption equilibrium and kinetics of $\mathrm{AC}$ in an aqueous system. The characterization of $\mathrm{AC}$ was also conducted to comprehend the effects of physicochemical properties of $\mathrm{AC}$ on $\mathrm{Hg}$ adsorption.

\section{Physicochemical properties of $A C$}

Commercial granular activated carbon (Wel Han Environmental Industrial Co., Taiwan) prepared from high-quality coconut shell was used. The AC was first washed with deionized water to remove fine particle and impurity, then dried at $60^{\circ} \mathrm{C}$ in a drying oven for $24 \mathrm{~h}$. After cooling in the drying oven, the AC was sieved by 10-18 mesh (1-2 $\mathrm{mm}$ ) standard screens and stored for subsequent tests.

The specific surface area $\left(\mathrm{S}_{\mathrm{BET}}\right)$, total pore volume $\left(\mathrm{V}_{\text {total }}\right)$, and micropore surface area $\left(\mathrm{S}_{\text {micro }}\right)$ and micropore surface are $\left(\mathrm{V}_{\text {micro }}\right)$ of $\mathrm{AC}$ were determined by $\mathrm{N}_{2}$ adsorption isotherm at $77 \mathrm{~K}$ (Micromeritics ASAP 2020). Brunauer-Emmett-Teller (BET) method was applied to evaluate $S_{B E T}, V_{\text {total }}$ was calculated by total $N_{2}$ volume adsorbed by $\mathrm{AC}$ at the relative pressure near one. The $\mathrm{t}$ plot method was applied to evaluate the micropore volume and micropore surface area. Non-local density functional theory (NLDFT) model was applied to evaluate the pore size distribution of micropore. BarrettJoyner-Halenda method was used to evaluate the pore size distribution of mesopore and macropore.

The morphology of AC samples was studied by scanning electron microscopy (SEM: JOEL JSM-7500F) with an accelerating voltage of $15 \mathrm{kV}$. AC was coated with a thin layer of gold to increase their electrical conductivity and stability, so that they can withstand the high vacuum conditions during analysis.

The elemental analyses were conducted to measure the contents of elements including nitrogen, carbon, hydrogen, sulfur (Vario EL cube, Elementar), and oxygen (Flash 2000, Thermo Fisher).

The zeta potential of AC under different pHs (1-9) was determined (Malvern Zetasizer Nano $\mathrm{Z}$ analyzer). $\mathrm{AC}$ was grounded into small powder for suspension in solution. Samples were prepared by adding $5 \mathrm{mg}$ of AC in $9 \mathrm{~mL}$ Milli-Q water and adjusted to a given $\mathrm{pH}$ with 
$\mathrm{NaOH}$ and $\mathrm{HNO}_{3}$. The total solution volume was around $10 \mathrm{~mL}$ for analysis.

X-ray photoelectron spectroscopy (XPS; ULVAC PHI5000 ) was conducted with $\mathrm{Al} \mathrm{K \alpha}$ radiation of $15 \mathrm{kV}$ to comprehend the functional groups on the surface of AC. The binding energies of peaks were referenced to $\mathrm{C} 1 \mathrm{~s}$ peak at $285 \mathrm{eV}$.

\section{Batch experiments of $\mathrm{Hg}$ adsorption}

The batch experiments include two parts: AC adsorption performance tests and $\mathrm{Hg}$ distribution tests. The AC adsorption performance experiments include $\mathrm{AC}$ dosage test and adsorption kinetic test. The AC dosage test was carried out by adding given amounts of $\mathrm{AC}$ into the spiked $\mathrm{Hg}$ solution in the absence of chloride, sulfide, and DOM. The adsorption kinetic test and $\mathrm{Hg}$ distribution test were carried out by using spiked $\mathrm{Hg}$ solution containing various concentrations of chloride, sulfide, and DOM individually under a fixed dosage of AC. The AC adsorption experiments in Hg-spiked solution mixed with chloride, sulfide, and DOM were designated as " $\mathrm{Hg}+\mathrm{Cl}^{\prime}$, " $\mathrm{Hg}+$ sulfide", and "Hg + DOM" respectively in this study. Each experiment was performed in triplicate. The main parameters are listed in Table S1 of Supplemental Materials.

\section{Preliminary work of solution preparation}

All solutions and reagents were prepared in degassed Milli-Q water, which was deoxygenated by purging with high-purity $\mathrm{N}_{2}$ at least 40 min (oxygen concentration $<2$ $\mathrm{mg} \mathrm{L}^{-1}$ ). The $\mathrm{Hg}^{2+}$ solutions were prepared by diluting $\mathrm{Hg}\left(\mathrm{NO}_{3}\right)_{2}$ standard solution to $20-40 \mu \mathrm{g} \mathrm{L}-1$ then adding $5 \mathrm{mM}$ sodium nitrate to maintain the ionic strength. Chloride stock solutions were prepared by dissolving sodium chloride in Milli-Q water. Sulfide stock solutions ( $\mathrm{pH}=11.5 \pm 0.5$ ) were prepared by dissolving crystals of $\mathrm{Na}_{2} \mathrm{~S} \cdot 9 \mathrm{H}_{2} \mathrm{O}$ in Milli-Q water containing $10 \mathrm{mM} \mathrm{H}_{3} \mathrm{BO}_{3}$ then used immediately. The concentrations of chloride stock and sulfide stock were determined by UV-Vis spectrophotometer (Merck Spectroquant ${ }^{\circ}$ Prove 300). DOM stock solutions were prepared by dissolving Suwanee River Humic Acid (SRHA) powder in Milli-Q water. The $\mathrm{pH}$ of the DOM stock was adjusted with $0.01 \mathrm{M}$ $\mathrm{NaOH}$ to $\mathrm{pH} 6$ then filtered through a $0.2 \mu \mathrm{m}$ filter and stored in a refrigerator at $4{ }^{\circ} \mathrm{C}$ until measuring the total dissolved organic carbon (DOC) with a total organic carbon (TOC) analyzer.

\section{AC adsorption performance}

The experimental process followed the steps below:

Preparation of $\mathbf{H g}$ solution The $\mathrm{Hg}$ stock was diluted to $20 \mu \mathrm{g} \mathrm{L}{ }^{-1}$ for AC dosage test. The " $\mathrm{Hg}+\mathrm{Cl}^{\text {" test was }}$ carried out by diluting $\mathrm{Hg}$ and chloride stock solution to $20 \mu \mathrm{g} \mathrm{L}^{-1}$ and $200 \mathrm{mM}$ respectively in a $1 \mathrm{~L}$ beaker. The
"Hg + DOM" test was carried out by diluting $\mathrm{Hg}$ and DOM stock solution to $20 \mu \mathrm{g} \mathrm{L}^{-1}$ and $2 \mathrm{mg} \mathrm{C} \mathrm{L}^{-1}$ in a 1 $\mathrm{L}$ beaker, respectively. The "Hg + sulfide" test was carried out by diluting $\mathrm{Hg}$ and sulfide stock solution to 40 $\mu \mathrm{g} \mathrm{L}{ }^{-1}$ and $20 \mu \mathrm{M}$ in each $500 \mathrm{~mL}$ beaker, respectively. Then, the sample solution was prepared by mixing equal volume of $\mathrm{Hg}$ and sulfide solution. Each $\mathrm{Hg}$ sample solution was adjusted to $\mathrm{pH} 7 \pm 0.5$ by using $0.01 \mathrm{M} \mathrm{NaOH}$ and $0.01 \mathrm{M} \mathrm{HNO}_{3}$ before adding $\mathrm{AC}$.

Sample preparation The $\mathrm{Hg}$ sample solution was separated in a $50 \mathrm{~mL}$ volumetric flask and injected into a 50 $\mathrm{mL}$ glass vessel. The intended dosage of $\mathrm{AC}$ was added into glass vessels, which were then covered with a rubber stopper and aluminum cap. All of the glass vessels were then coated with aluminum foil to avoid light effect.

Adsorption condition The samples were put into a water-bath incubating shaker and shaken at $125 \mathrm{rpm}$ for $30-2880 \mathrm{~min}$ at $30^{\circ} \mathrm{C}$.

Sample analysis For the AC dosage and " $\mathrm{Hg}+\mathrm{Cl}$ " test, $20 \mathrm{~mL}$ of the unfiltered initial $\mathrm{Hg}$ sample solution and 5 $\mathrm{mL}$ of the solution which was filtered with $0.2 \mu \mathrm{m}$ filter after $\mathrm{AC}$ adsorption were preserved and digestion with $0.5 \% \mathrm{BrCl}$ at least 1 day before the total $\mathrm{Hg}$ concentration (THg) analysis. For "Hg + sulfide" and "Hg + DOM" tests, $20 \mathrm{~mL}$ of the initial $\mathrm{Hg}$ sample solution and $5 \mathrm{~mL}$ of the solution which was filtered with $0.2 \mu \mathrm{m}$ filter after $\mathrm{AC}$ adsorption were preserved with $0.5 \% \mathrm{BrCl}$ and stored in a refrigerator at $4{ }^{\circ} \mathrm{C}$ until microwave digestion by $\mathrm{HCl}$ mixed with $\mathrm{HNO}_{3}(3: 1 \mathrm{v} / \mathrm{v})$. All the water samples were analyzed for the THg by the cold vapor atomic fluorescence spectrophotometer (CVAFS: Brooks Rand Model 3). The aqueous $\mathrm{Hg}$ removal efficiency by $\mathrm{AC}$ was calculated by Eq. (1) and the adsorption capacity of AC was calculated by Eq. (2).

$$
\begin{aligned}
& \mathrm{R}(\%)=\frac{C_{0}-C_{t}}{C_{0}} \times 100 \% \\
& q_{e}\left(\mu g g^{-1}\right)=\frac{\left(C_{0}-C_{t}\right) \times V}{W_{A C}}
\end{aligned}
$$

where $\mathrm{R}(\%)$ is the $\mathrm{Hg}$ removal efficiency, $\mathrm{q}_{\mathrm{e}}\left(\mu \mathrm{g} \mathrm{g}^{-1}\right)$ is the adsorption capacity of $\mathrm{AC}, \mathrm{C}_{0}\left(\mu \mathrm{g} \mathrm{L}^{-1}\right)$ is the initial $\mathrm{Hg}$ concentration, $\mathrm{C}_{\mathrm{t}}\left(\mu \mathrm{g} \mathrm{L}^{-1}\right)$ is the residual $\mathrm{Hg}$ concentration at given time, $\mathrm{V}(\mathrm{L})$ is the volume of $\mathrm{Hg}$ sample solution, and $\mathrm{W}_{\mathrm{AC}}(\mathrm{mg})$ is the dosage of $\mathrm{AC}$.

To determine the optimum AC dosage for the batch experiments, $\mathrm{AC}$ dosage tests were carried out by adding 20, 50, and $80 \mathrm{mg} \mathrm{AC}$ in $50 \mathrm{~mL} \mathrm{Hg}$ solution $\left(20 \mu \mathrm{g} \mathrm{L}{ }^{-1}\right)$. The contact time of AC in " $\mathrm{Hg}$ + sulfide" test was controlled at 30,60,300, 600, and $1200 \mathrm{~min}$. The contact time of $\mathrm{AC}$ in " $\mathrm{Hg}+\mathrm{Cl}$ " and "Hg + DOM" tests were 
controlled at 30,60, 300, 960, 1440, and $2880 \mathrm{~min}$. The test parameters are listed in Table S2.

\section{Hg distribution test}

The purpose of this part of experiment is to realize the $\mathrm{Hg}$ distribution, including $\mathrm{Hg}$ in dissolved and solid phases under different concentration levels of sulfide/ chloride/DOM. The test sample was divided into three parts by operational-defined method included "dissolved $\mathrm{Hg}$ ", "particulate $\mathrm{Hg}$ ", and " $\mathrm{Hg}$ in $\mathrm{AC}$ ". The parameters are listed in Table S3. The experimental process was basically the same as the step of AC adsorption performance. The process followed the steps below:

Preparation of $\mathrm{Hg}$ solution $\mathrm{The}$ " $\mathrm{Hg}+\mathrm{Cl}$ " and " $\mathrm{Hg}+$ DOM" tests were carried out using chloride/DOM solutions containing $20 \mu \mathrm{g} \mathrm{L}{ }^{-1} \mathrm{Hg}$ in a $1 \mathrm{~L}$ beaker. The " $\mathrm{Hg}$ $+S$ " test was carried out by mixing the equal volume $(500 \mathrm{~mL})$ of different concentrations of sulfide with $\mathrm{Hg}$ solution $\left(40 \mu \mathrm{g} \mathrm{L}^{-1}\right)$ to have the solutions containing $20 \mathrm{gg} \mathrm{L}^{-1} \mathrm{Hg}$. Each $\mathrm{Hg}$ solution was adjusted to $\mathrm{pH}$

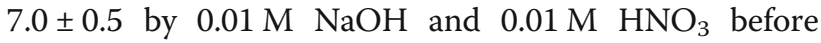
adding AC.

Sample preparation The $\mathrm{Hg}$ solution was quantitated for $50 \mathrm{~mL}$ by volumetric flasks and injected into each glass vessel. The AC was then added into glass vessels and covered with a rubber stopper and aluminum cap. All of the glass vessels were then coated with aluminum foil to avoid light effect.

Adsorption condition The samples were put into a water-bath incubating shaker and shaken at $125 \mathrm{rpm}$ for $1440 \mathrm{~min}$ at $30^{\circ} \mathrm{C}$.

\section{Sample analysis}

(1) Dissolved Hg

The residual $\mathrm{Hg}$ in the solution after $\mathrm{AC}$ adsorption was defined as "dissolved $\mathrm{Hg}$ ". For the " $\mathrm{Hg}+\mathrm{Cl}$ " test, 5 $\mathrm{mL}$ of the solution which was filtered with $0.2 \mu \mathrm{m}$ filter after AC adsorption was preserved and digestion with $0.5 \% \mathrm{BrCl}$ at least 1 day before $\mathrm{THg}$ analysis. For the "Hg $+\mathrm{S}$ " and "Hg + DOM" tests, $5 \mathrm{~mL}$ of the solution which was filtered with $0.2 \mu \mathrm{m}$ filter after $\mathrm{AC}$ adsorption was preserved with $0.5 \% \mathrm{BrCl}$ and stored in a refrigerator at $4{ }^{\circ} \mathrm{C}$ until microwave digestion by $\mathrm{HCl}$ mixed with $\mathrm{HNO}_{3}(3: 1 \mathrm{v} / \mathrm{v})$. All the water samples were analyzed for THg by CVAFS.

\section{(2) Particulate Hg}

The particles formed by $\mathrm{Hg}$ interacted with sulfide or DOM were defined as "particulate $\mathrm{Hg}$ ". The residual solution was filtered by $0.2 \mu \mathrm{m}$ cellulose acetate membrane filter to intercept the particulate $\mathrm{Hg}$. The membrane filter was preserved in a centrifuge tube and stored at $-20^{\circ} \mathrm{C}$. Then, freeze dryer system was used to remove moisture. The dried particulate $\mathrm{Hg}$ sample was microwave digested by $\mathrm{HCl}$ mixed with $\mathrm{HNO}_{3}(3: 1 \mathrm{v} / \mathrm{v})$. The samples were estimated for $\mathrm{Hg}$ by CVAFS.

\section{(3) $\mathrm{Hg}$ in $\mathrm{AC}$}

AC collected by manual screening after adsorption was defined as " $\mathrm{Hg}$ in $\mathrm{AC}$ ". After the residual solution was filtered by $0.2 \mu \mathrm{m}$ cellulose acetate membrane filter and rinsing the glass vessel with Milli-Q water, the AC sample was collected by manual screening and stored at $-20^{\circ} \mathrm{C}$. Then, freeze dryer system was used to remove moisture. The AC sample was microwave digested by $\mathrm{HCl}$ mixed with $\mathrm{HNO}_{3}(3: 1 \mathrm{v} / \mathrm{v})$. The samples were estimated for $\mathrm{Hg}$ by CVAFS and the actual $\mathrm{q}_{\mathrm{e}}$ of $\mathrm{AC}$ was subsequently determined.

\section{Sample analysis}

The $\mathrm{THg}$ in the aqueous sample was determined by CVAFS. The method detection limit of CVAFS used in this study is $0.26 \mathrm{n} \mathrm{L} \mathrm{L}^{-1}$. TOC in the water sample is oxidized to form $\mathrm{CO}_{2}$, which is then measured by a detection system (Aurora 1030w). The sulfide and chloride analyses were done by test kits and measured in the photometer (Merck Spectroquant ${ }^{\circ}$ Prove 300). Detailed descriptions pertaining to the analyses of $\mathrm{THg}, \mathrm{TOC}$, sulfide, and chloride can be found in the Supplementary Materials.

\section{Results and discussion}

Physical and chemical properties of AC

Table 1 shows the physical and chemical properties of AC. The $S_{\text {BET }}$ and $S_{\text {micro }}$ were 818 and $769 \mathrm{~m}^{2} \mathrm{~g}^{-1}$, respectively, and the microporosity (i.e., $\mathrm{V}_{\text {micro }} / \mathrm{V}_{\text {total }}$ ) was calculated to be 0.868 , indicating that the $\mathrm{AC}$ used in this study is highly microporous (pore $<2 \mathrm{~nm}$ ). This result is also supported by the pore size distribution based on NLDFT method (Fig. 1). SEM images of AC also showed that the AC used are particles with sizes around 1-1.5 $\mathrm{mm}$ with significant surface roughness that may increase the macropore and surface defects. As a result, without any surface modification process, the AC used retained a well-developed pore structure and distribution that could be beneficial for $\mathrm{Hg}$ adsorption. It is worth noting that the presence of micropores is essential for the $\mathrm{Hg}$ adsorption; the micropore surface area or volume, however, does not appear to be the only property that affects the Hg adsorption effectiveness [30]. The presence of active sites, such as oxygenated functional groups in activated carbon, also governs the $\mathrm{Hg}$ adsorption. 
Table 1 The physicochemical properties of AC

\begin{tabular}{llccccccc}
\hline $\mathbf{S}_{\text {BET }}\left(\mathbf{m}^{\mathbf{2}} \mathbf{g}^{-\mathbf{1}}\right)$ & $\mathbf{S}_{\text {micro }}\left(\mathbf{m}^{\mathbf{2}} \mathbf{g}^{-\mathbf{1}}\right)$ & $\mathbf{V}_{\text {total }}\left(\mathbf{c m}^{\mathbf{3}} \mathbf{g}^{-\mathbf{1}}\right)$ & $\mathbf{V}_{\text {micro }}\left(\mathbf{c m}^{\mathbf{3}} \mathbf{g}^{-\mathbf{1}}\right)$ & $\mathbf{C}(\mathbf{w t} \%)$ & $\mathbf{H}(\mathbf{w t} \%)$ & $\mathbf{O}(\mathbf{w t} \%)$ & $\mathbf{N}(\mathbf{w t} \%)$ & $\mathbf{S}(\mathbf{w t} \%)$ \\
\hline 818 & 769 & 0.462 & 0.401 & 78.9 & 1.41 & 4.52 & 0.73 & 0.47 \\
\hline
\end{tabular}

AC was mainly composed of $78.9 \mathrm{wt} \% \mathrm{C}, 4.52 \mathrm{wt} \% \mathrm{O}$, $1.41 \mathrm{wt} \% \mathrm{H}$, and $0.73 \mathrm{wt} \% \mathrm{~N}$ (Table 1). There was also a minor content of sulfur $(0.47 \mathrm{wt} \%)$ in $\mathrm{AC}$, however, it was not apparently existed as a functional group to adsorb $\mathrm{Hg}$ as shown in XPS because the peak intensity of S2p was weak (Fig. 2). XPS spectra of AC include (a) wide scan, (b) deconvoluted $\mathrm{C} 1 \mathrm{~s}$, and (c) the deconvoluted O1s. The $\mathrm{C} 1 \mathrm{~s}$ spectra of AC in Fig. $2 \mathrm{~b}$ could be deconvoluted into four peaks at the binding energies of 284.6, 286.0, 287.6, and $290.4 \mathrm{eV}$, corresponded to $\mathrm{C}-\mathrm{C}, \mathrm{C}-\mathrm{OH}, \mathrm{C}=\mathrm{O}$ and $\mathrm{COOH}$, respectively, according to Martinez et al. [31]. The O1s spectra of AC in Fig. 2c was deconvoluted into six peaks at the binding energies of 530.2, 531.1, 531.8, 532.5, 533.4,
534.5, and $538.4 \mathrm{eV}$, corresponded to quinone, $\mathrm{COOH}, \mathrm{C}=$ $\mathrm{O}, \mathrm{C}-\mathrm{O}, \mathrm{C}-\mathrm{OH}$, and chemisorbed oxygen, respectively [32]. The test AC contained numerous oxygen functional groups, which were well known as effective adsorption sites for $\mathrm{Hg}$ [33, 34]. Li et al. [35] also suggested that oxygen surface complexes, possibly lactone $\left(\mathrm{COO}^{-}\right)$and carbonyl $(\mathrm{C}=$ $\mathrm{O})$ groups, are the potential sites for $\mathrm{Hg}$ capture.

Figure 3 shows the zeta potential of AC under different $\mathrm{pH}$ within 1-9. The zero point of charge of $\mathrm{AC}$ in Milli-Q water was shown to be around $\mathrm{pH} 1$. Therefore, whether AC exists in natural environment or in the condition of this study $(\mathrm{pH}=7)$, the surface charge of $\mathrm{AC}$ is always negative.
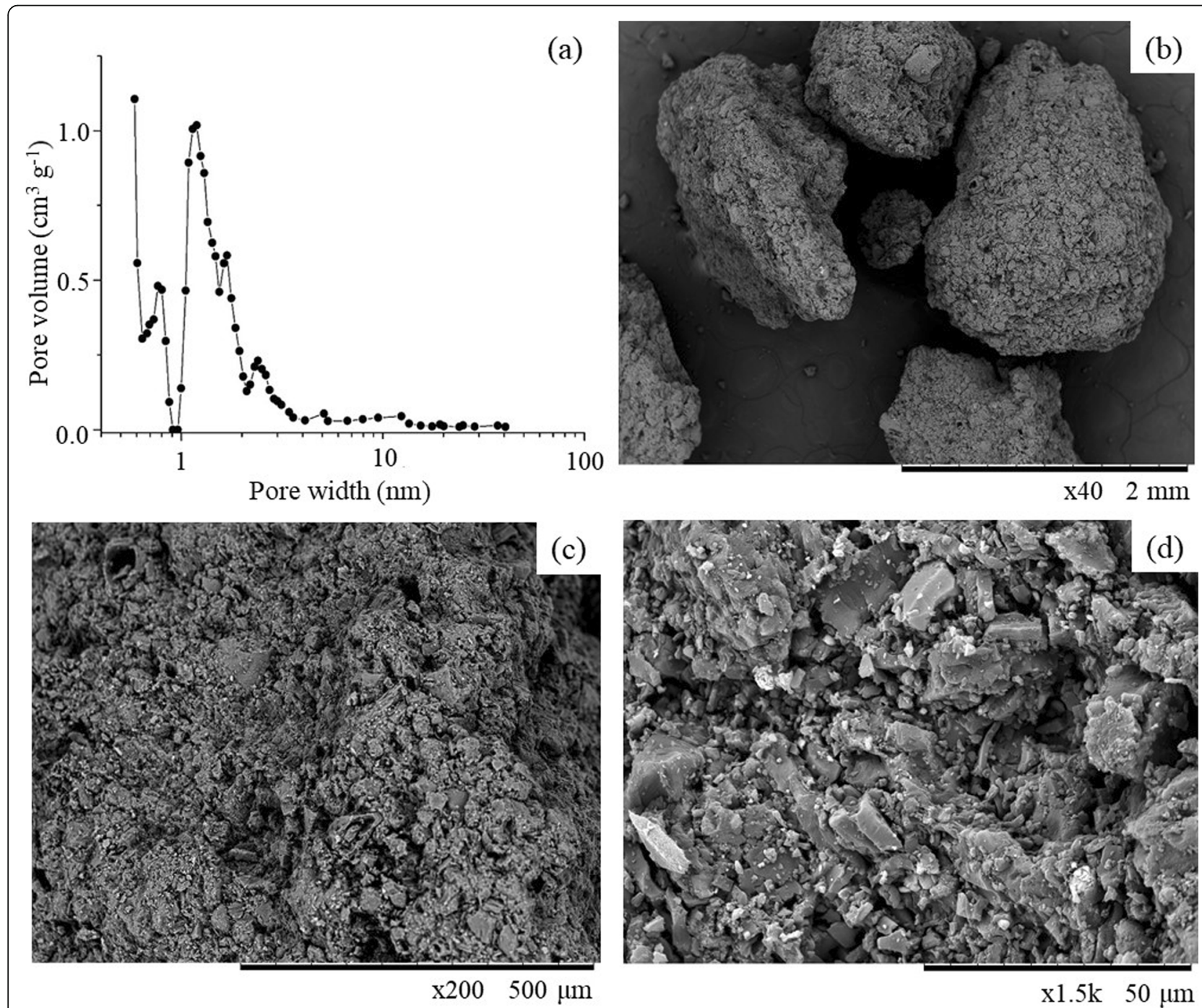

Fig. 1 a The pore size distribution of AC based on NLDFT model and the SEM images of AC under b 40; c 200; and $\mathbf{d} 1500 \times$ magnification 

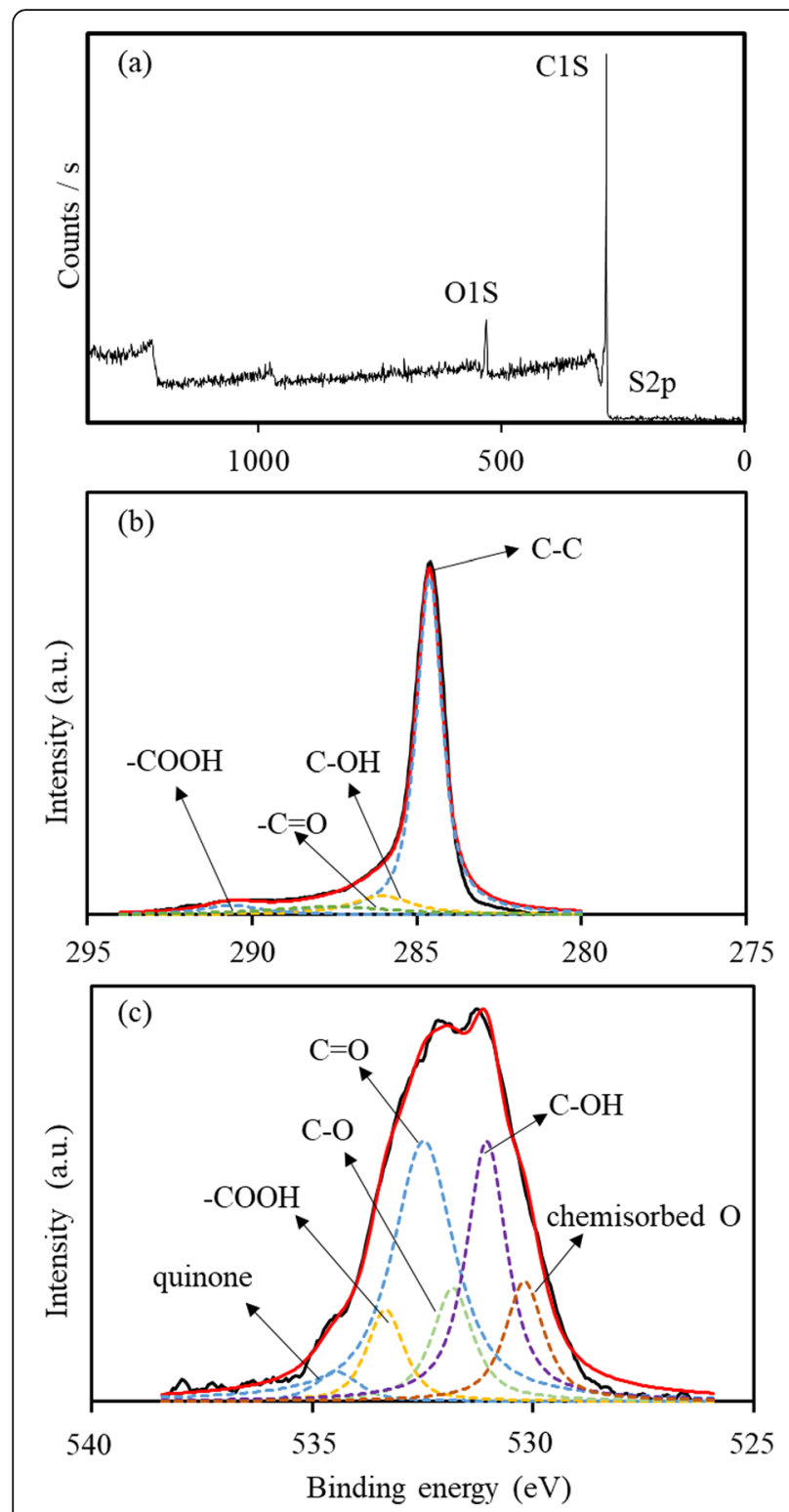

Fig. 2 XPS spectrum in AC of a full scan; b C1s; c O1s

\section{$\mathrm{Hg}$ adsorption performance by $\mathrm{AC}$}

The AC dosage test was to determine the appropriate dosage for the batch experiments with a given initial $\mathrm{Hg}$ concentration. The past study showed that the contact time of $\mathrm{Hg}$ adsorption by $\mathrm{AC}$ was approximately $16 \mathrm{~h}$ to reach equilibrium [13]. To ensure reaching equilibrium, the contact time was set for $24 \mathrm{~h}$ in this part of batch experiments.

The initial $\mathrm{Hg}$ concentration was $18.4 \mu \mathrm{g} \mathrm{L}^{-1}$ under different AC dosages. The results of dosage test are listed in Table 2. This result shows that the increase in $\mathrm{Hg}$ removal efficiency and the decrease in adsorption capacity became less significant at the dosage from 50 to $80 \mathrm{mg}$. Therefore, $50 \mathrm{mg}$ AC was considered as the suitable dosage for the following experiments in this study.
The Hg adsorption kinetics are different in the presence of chloride, sulfide, and DOM in the aqueous phase. Table 3 shows the test condition and the adsorption results under various contact time of $\mathrm{Hg}$ adsorption in the presence of chloride, sulfide, or DOM. Figure 4 further shows the residual dissolved $\mathrm{Hg}$ in the solution under various contact time up to $48 \mathrm{~h}$. These experimental results suggest that the behaviors of $\mathrm{Hg}$ adsorption are significantly different in " $\mathrm{Hg}+\mathrm{Cl}$ ", "Hg + sulfide", and " $\mathrm{Hg}+$ DOM" conditions. To reach equilibrium, the contact time was at least 16,10 , and $24 \mathrm{~h}$ in " $\mathrm{Hg}+\mathrm{Cl}$ ", " $\mathrm{Hg}+$ sulfide", and "Hg + DOM" conditions, respectively. In order to further understand the possible $\mathrm{Hg}$ adsorption mechanisms, the adsorption kinetic models should be discussed. The equations of pseudo-first-order, pseudo-second order, and intraparticle diffusion model are given in Eqs. (3)-(5) and the fitting results are shown in Table 4.

$$
\begin{aligned}
& \log \left(q_{e 1}-q_{t}\right)=\log \left(q_{e 1}\right)-\frac{k_{1} t}{2.303} \\
& \frac{t}{q_{t}}=\frac{1}{\left(k_{2} \times q_{e 2}^{2}\right)}+\frac{t}{q_{e 2}} \\
& q_{t}=k_{p} \times t^{0.5}+C
\end{aligned}
$$

Data obtained in "Hg $+\mathrm{Cl}$ " condition had high $\mathrm{R}^{2}$ (0.9998 and 0.9828) by pseudo-first order and pseudosecond order model fitting (Table 4). However, the calculated $\mathrm{q}_{\mathrm{e} 2}$ is more approximate to the experimental $\mathrm{q}_{\mathrm{e}}$. Data obtained in "Hg + sulfide" condition had a higher $\mathrm{R}^{2}(0.9998)$ by pseudo-second order model fitting than $\mathrm{R}^{2}$ (0.6886) by pseudo-first order model fitting. Data obtained in "Hg + DOM" condition had higher $\mathrm{R}^{2}(0.9843)$ by pseudo-first order model fitting than $\mathrm{R}^{2}(0.8503)$ by pseudo-second order model fitting. However, both the calculated $\mathrm{q}_{\mathrm{e} 1}$ and $\mathrm{q}_{\mathrm{e} 2}$ are similar to experimental $\mathrm{q}_{\mathrm{e}}$ in "Hg + DOM" condition. Therefore, the Hg adsorption by $\mathrm{AC}$ in " $\mathrm{Hg}+\mathrm{Cl}$ " and " $\mathrm{Hg}+\mathrm{DOM}$ " conditions may follow both pseudo-first order and pseudo-second order reaction mechanisms. The fitting result for "Hg + DOM" condition was similar to Singh et al. [36], which reported that the adsorption of $\mathrm{Hg}$ interacted with organic ligands by kaolinite obeyed multiple first order kinetics. In the multiple first order kinetics adsorption process, they suggested that one stage corresponds to the initial binding with the active sites of the solid surface [37]. In this study, the reaction of $\mathrm{Hg}$ adsorption might be directly binding on $\mathrm{AC}$ with $\mathrm{Hg}-\mathrm{Cl}$ and $\mathrm{Hg}$-DOM complexes. However, the $\mathrm{Hg}$ adsorption reaction in " $\mathrm{Hg}+$ sulfide" condition was significantly different. The adsorption mechanism for "Hg $+\mathrm{S}$ " condition was more likely to fit pseudo-second order reaction based on the assumption that the rate-limiting step may be chemical adsorption 


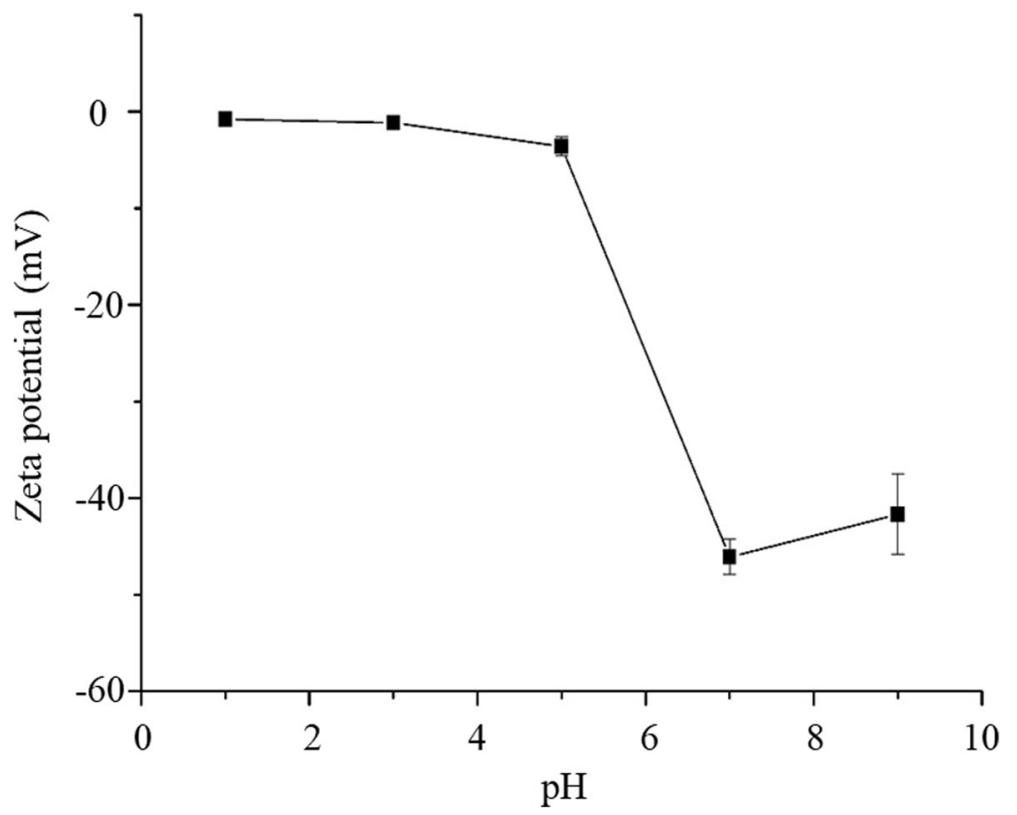

Fig. 3 Zeta potential of $\mathrm{AC}$ at different $\mathrm{pH}$

or chemisorption involving valance forces through sharing or exchange of electrons [37]. Since a high affinity of sulfide bind to $\mathrm{Hg}$, precipitation of $\mathrm{Hg}$ occurred in the adsorption process. The pseudo-first order rate constants $\mathrm{k}_{1}$ for " $\mathrm{Hg}+\mathrm{Cl}^{-}$and " $\mathrm{Hg}+$ DOM" were 0.0023 and $0.0009 \mathrm{~min}^{-1}$ respectively. The pseudo-second order rate constants $\mathrm{k}_{2}$ for " $\mathrm{Hg}+$ $\mathrm{Cl}$ ", "Hg + S", and "Hg + DOM" were 0.00057, 0.014 and $0.00022 \mathrm{~g} \mathrm{\mu g}^{-1} \mathrm{~min}^{-1}$. The additional sulfide promoted the reaction rate of $\mathrm{Hg}$ adsorption by $\mathrm{AC}$ due to the precipitation of $\mathrm{HgS}$. Conversely, DOM decreased the $\mathrm{Hg}$ adsorption rate dramatically. $\mathrm{Hg}$, a soft Lewis acid, has a strong affinity for thiol functional groups in DOM. Song et al. [27] reported that $\mathrm{Hg}$ interacting with natural organic matter had high thermodynamic stability. Past research has suggested that the complexation of $\mathrm{Hg}$ by DOM thiol groups could hinder nanoparticle $\beta-\mathrm{HgS}$ growth $[38,39]$. For inference, the same mechanism could occur in the $\mathrm{Hg}+\mathrm{DOM}$ adsorption by AC. DOM worked as a barrier to inhibit the contact of $\mathrm{Hg}$ with $\mathrm{AC}$; therefore, adsorption in "Hg + DOM" condition had the lowest rate constant.

Table 2 The $\mathrm{Hg}$ adsorption results at various AC dosage

\begin{tabular}{|c|c|c|c|}
\hline AC dosage $(\mathrm{mg})$ & 20 & 50 & 80 \\
\hline THg removal (\%) & 89 & 94 & 97 \\
\hline Adsorption capacity $\left(\mu \mathrm{g} \mathrm{g}^{-1}\right)$ & 42.9 & 18.2 & 11.6 \\
\hline
\end{tabular}

The fitting results of intraparticle diffusion is also shown in Table 4. Data obtained in " $\mathrm{Hg}+\mathrm{Cl}$ " and "Hg + DOM" condition had higher $\mathrm{R}^{2}(0.9980$ and 0.9508$)$. Therefore, the $\mathrm{Hg}$ adsorption by $\mathrm{AC}$ in " $\mathrm{Hg}+\mathrm{Cl}$ " and " $\mathrm{Hg}+\mathrm{DOM}$ " conditions are more likely depended on intraparticle diffusion. The intraparticle diffusion rate constants $k_{p}$ for " $\mathrm{Hg}+\mathrm{Cl}$ " and " $\mathrm{Hg}+\mathrm{DOM}^{\circ}$ were 0.40 and $0.25 \mu \mathrm{g} \mathrm{g}^{-1}$ $\min ^{-0.5}$ respectively. The four basic steps of adsorption in a porous adsorbent included bulk solution transport, external transport, internal transport, and adsorption [40]. The AC used in this study is a porous adsorbent with high volume of micropores. The rate-limiting step in " $\mathrm{Hg}+\mathrm{Cl}$ " and " $\mathrm{Hg}+\mathrm{DOM}$ " is likely toward to intraparticle diffusion.

Table 3 The equilibrium results of $\mathrm{Hg}$ adsorption in the presence of chloride, sulfide, or DOM

\begin{tabular}{llll}
\hline & $\mathbf{H g}+\mathbf{C l}$ & $\mathbf{H g}+$ sulfide & $\mathbf{H g}+\mathbf{D O M}$ \\
\hline Initial experimental parameters & & & \\
$\mathrm{Hg}$ conc. $\left(\mu \mathrm{g} \mathrm{L}^{-1}\right)$ & 16.2 & 18.6 & 20.4 \\
Factor conc. & $200 \mathrm{mM}$ & $10 \mu \mathrm{M}$ & $2 \mathrm{mg} \mathrm{C} \mathrm{L}^{-1}$ \\
$\mathrm{pH}$ & 6.86 & 6.76 & 6.96 \\
Dissolved $\mathrm{O}_{2}\left(\mathrm{mg} \mathrm{L}^{-1}\right)$ & 4.13 & 4.33 & 4.33 \\
Contact time (min) & $0-2880$ & $0-1440$ & $0-2880$ \\
After reaching equilibrium & & & \\
Residual dissolved THg $\left(\mu \mathrm{L} \mathrm{L}^{-1}\right)$ & 1.84 & 3.34 & 9.99 \\
THg removal (\%) & 89 & 82 & 51 \\
Adsorption capacity $\left(\mu \mathrm{g} \mathrm{g}^{-1}\right)$ & 14.3 & 15.3 & 10.4 \\
\hline
\end{tabular}

The liquid volume: $50 \mathrm{~mL}$; AC dosage: $50 \mathrm{mg}$; shaking speed: $125 \mathrm{rpm}$; temperature: $30^{\circ} \mathrm{C}$; contact time: $24 \mathrm{~h}$ 


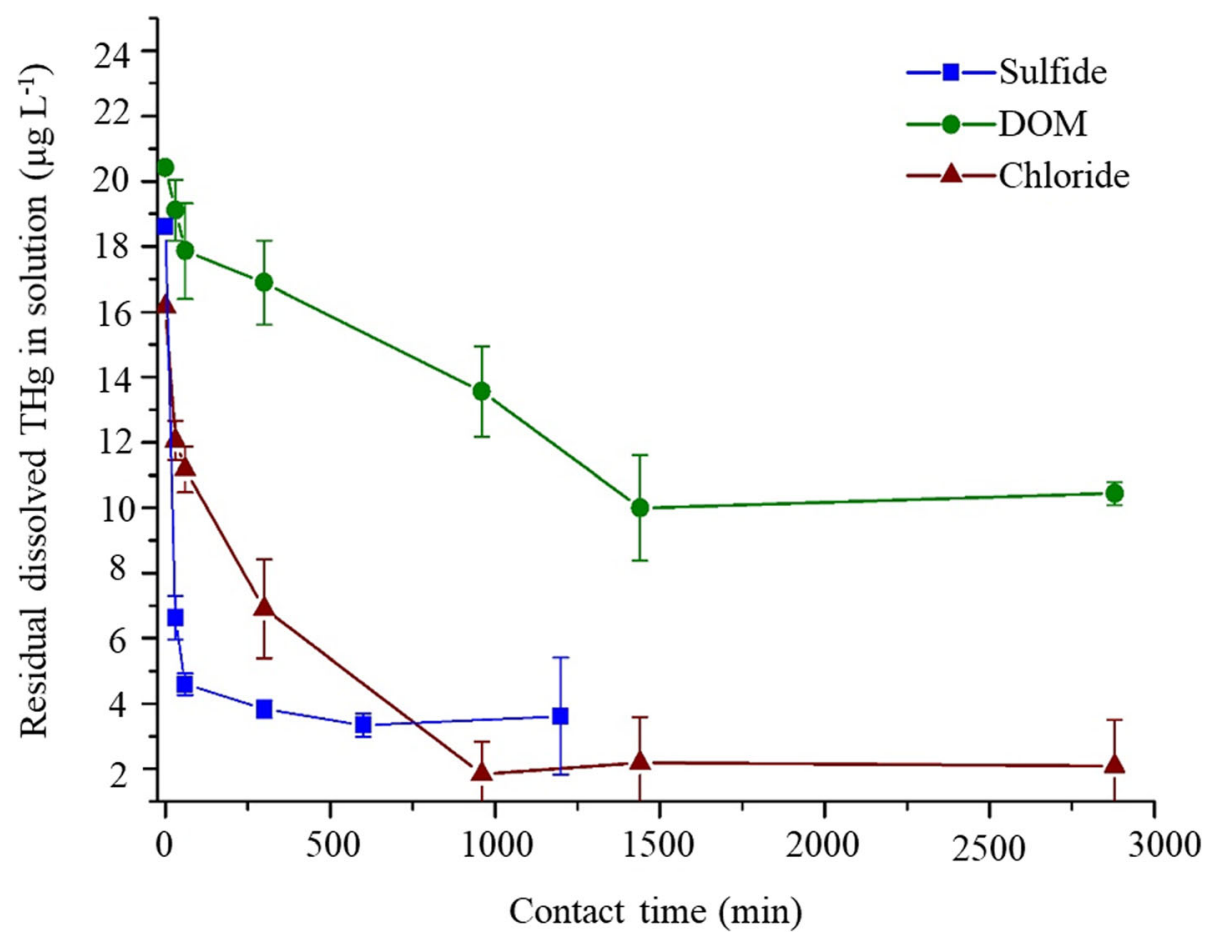

Fig. 4 The residual dissolved THg in solution under various contact time

Therefore, the adsorption rates are low in the " $\mathrm{Hg}+\mathrm{Cl}$ " and "Hg + DOM" conditions.

\section{Preliminary adsorption capacity comparison}

Tables 2 and 3 show the adsorption capacity $\left(\mathrm{q}_{\mathrm{e}}\right)$ of AC with and without additional chloride, sulfide, or DOM. The $\mathrm{q}_{\mathrm{e}}$ in the absence of these environmental factors $\left(18.18 \mu \mathrm{g} \mathrm{g}^{-1}\right)$ was slightly higher than the $\mathrm{q}_{\mathrm{e}}$ in the " $\mathrm{Hg}+$ Cl" $\left(14.32 \mu \mathrm{gg}^{-1}\right)$ and "Hg + sulfide" $\left(15.26 \mu \mathrm{g} \mathrm{g}^{-1}\right)$

Table 4 The fitting results based on the pseudo-first, pseudosecond order and intraparticle diffusion kinetic models

\begin{tabular}{llll}
\hline & $\mathbf{H g}+\mathbf{C l}$ & $\mathbf{H g}+\mathbf{S}$ & $\mathbf{H g}+\mathbf{D O M}$ \\
\hline Pseudo first-order & & & \\
$\mathrm{k}_{1}\left(\mathrm{~min}^{-1}\right)$ & 0.0023 & 0.0023 & 0.0009 \\
$\mathrm{q}_{\mathrm{e}}\left(\mu \mathrm{g} \mathrm{g}^{-1}\right)$ & 10.7 & 1.7 & 8.9 \\
$\mathrm{R}^{2}$ & 0.9998 & 0.6886 & 0.9843 \\
Pseudo second-order & & & \\
$\mathrm{k}_{2}\left(\mathrm{~g} \mathrm{\mu g}^{-1} \mathrm{~min}^{-1}\right)$ & 0.00057 & 0.014 & 0.00022 \\
$\mathrm{q}_{\mathrm{e} 2}\left(\mathrm{\mu g} \mathrm{g}^{-1}\right)$ & 16.1 & 15.4 & 11.6 \\
$\mathrm{R}^{2}$ & 0.9828 & 0.9998 & 0.8503 \\
Intraparticle diffusion & & & \\
$\mathrm{k}_{\mathrm{p}}\left(\mu \mathrm{gg} \mathrm{g}^{-1} \mathrm{~min}^{-0.5}\right)$ & 0.40 & 0.14 & 0.25 \\
$\mathrm{R}^{2}$ & 0.9980 & 0.7467 & 0.9508 \\
Experimental $\mathrm{q}_{\mathrm{e}}\left(\mu \mathrm{g} \mathrm{g} \mathrm{g}^{-1}\right)$ & 14.3 & 15.3 & 10.4 \\
\hline
\end{tabular}

conditions. AC in "Hg + DOM" condition had the lowest $\mathrm{q}_{\mathrm{e}}\left(10.4 \mu \mathrm{g} \mathrm{g}^{-1}\right)$. In past studies, chloride interacting with $\mathrm{Hg}$ to form a stable complex was considered as the reason for decreasing the $\mathrm{q}_{\mathrm{e}}$ of adsorbent [41, 42]. The additional sulfide seems to affect $\mathrm{Hg}$ adsorption on $\mathrm{AC}$ slightly. The DOM not only retarded $\mathrm{Hg}$ adsorption on $\mathrm{AC}$ but also decreased the $\mathrm{q}_{\mathrm{e}}$ significantly. The more detailed discussion on these effects on $\mathrm{q}_{\mathrm{e}}$ is presented in later section.

The calculation of $\mathrm{q}_{\mathrm{e}}$ is generally done by measuring the $\mathrm{Hg}$ concentration changes in aqueous phase before and after AC adsorption. There was a doubt appeared that whether $\mathrm{Hg}$ actually adsorbed on $\mathrm{AC}$ or not because the $\mathrm{q}_{\mathrm{e}}$ might be overestimated if $\mathrm{Hg}$ is reduced into $\mathrm{Hg}^{\mathrm{O}}$ and escaped into the air. Therefore, the investigation of $\mathrm{Hg}$ recovery by mass balance is necessary to ensure the accuracy of calculated $\mathrm{q}_{\mathrm{e}}$. In order to realize the influence of chloride on $\mathrm{Hg}$ adsorption, the recovery based on $\mathrm{Hg}$ mass balance before and after adsorption in the absence and presence of chloride had to be explored first (Fig. 5). The Hg recovery in the absence of chloride was $43 \%$. The $\mathrm{Hg}$ recovery in the presence of chloride was 92\%. Therefore, a various level of $\mathrm{Hg}$ could be escaped into the air in the absence of chloride. The reason for causing escape of $\mathrm{Hg}$ was due to the high $\mathrm{pH}$ value $(\mathrm{pH}=7)$ of $\mathrm{Hg}$ solution. Chen et al. [43] reported that $\mathrm{Hg}^{0}$ reemission rates from the wet flue gas desulfurization slurry increased about $4 \mu \mathrm{g} \mathrm{m}^{-3}$ as the $\mathrm{pH}$ values increased from 3 to 7 ; the $\mathrm{Hg}^{0}$ reemission rate decreased 


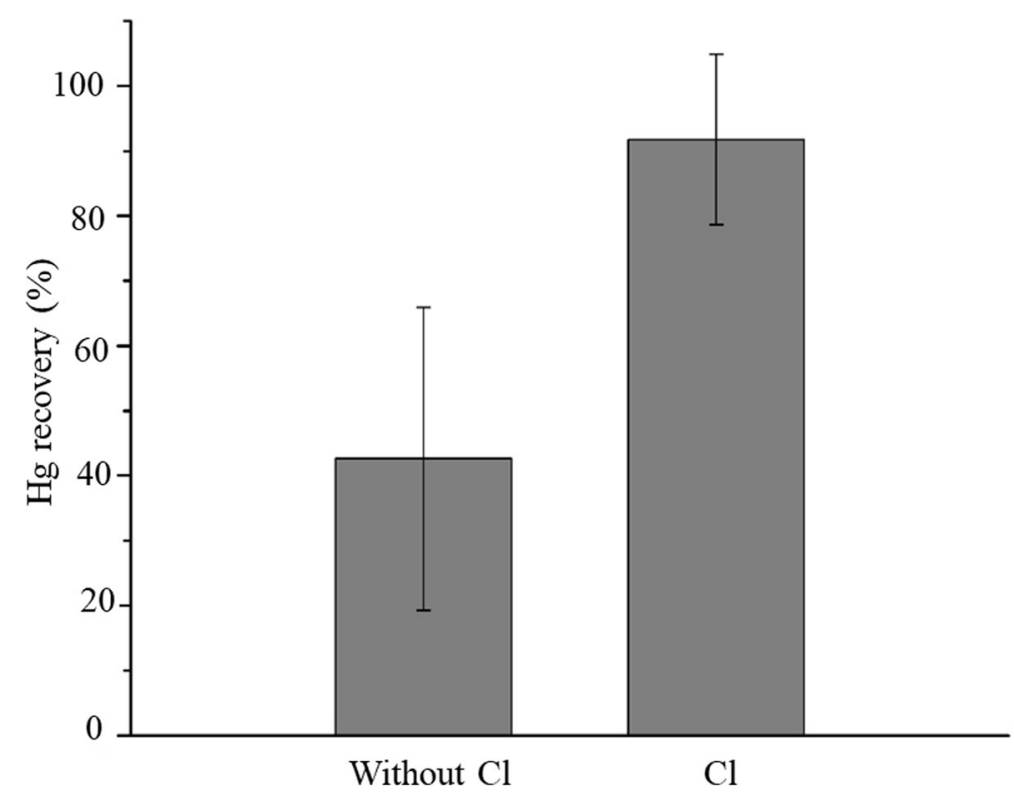

Fig. $5 \mathrm{Hg}$ recovery test without and with chloride (200 mM). Initial $\mathrm{Hg}$ conc:: $19.3 \mu \mathrm{g} \mathrm{L}{ }^{-1}$; volume: $50 \mathrm{~mL}$; $\mathrm{AC}$ dosage: 0 mg; $\mathrm{pH}=7$; shaking speed: $125 \mathrm{rpm}$; temperature: $30^{\circ} \mathrm{C}$; contact time: $24 \mathrm{~h}$

with increases chloride concentration. The acid condition could remain $\mathrm{Hg}^{2}{ }^{+}$in the dissolved phase, as a result, $\mathrm{Hg}$ adsorption test was generally carried out under $\mathrm{pH} 3-5[41,44,45]$. However, the range of $\mathrm{pH}$ value is $6-8$ in natural aquatic system. Therefore, it is reasonable to observe the apparent escape of $\mathrm{Hg}$ in this experimental condition $(\mathrm{pH}=7)$. Nevertheless, adding chloride could enhance stabilizing $\mathrm{Hg}$ in the solution due to forming $\mathrm{Hg}-\mathrm{Cl}$ complex. The phenomenon of $\mathrm{Hg}$ escaping into the air may thus possibly happen in this study as a result of the $\mathrm{pH}$ condition.

\section{$\mathrm{Hg}$ distribution test results}

The purpose of this part of the experiment is to realize the $\mathrm{Hg}$ distribution, including $\mathrm{Hg}$ in dissolved $(<0.2 \mu \mathrm{m})$ and solid phases $(>0.2 \mu \mathrm{m})$ under different concentration levels of sulfide/chloride/DOM. The test sample was divided into three parts including "dissolved $\mathrm{Hg}$ ", "particulate $\mathrm{Hg}$ ", and " $\mathrm{Hg}$ in $\mathrm{AC}$ ".

\section{$\mathrm{Hg}+\mathrm{Cl}$ " condition}

The " $\mathrm{Hg}+\mathrm{Cl}$ " test was carried out by conducting $\mathrm{Hg}$ adsorption by AC under the chloride concentration of 1 , 200 , and $400 \mathrm{mM}$. Table 5 describes the experimental parameters and the results of $\mathrm{Hg}$ distribution. The proportion of "dissolved $\mathrm{Hg}$ " under chloride concentration 1,200 , and $400 \mathrm{mM}$ was calculated to be $2.7,7.9$, and $4.8 \%$, respectively. The $\mathrm{Hg}$ removal efficiency was similar under the chloride concentration of 1,200 , and $400 \mathrm{mM}$ and more than $90 \%$ of $\mathrm{Hg}$ was removed. The proportion of "Hg in AC" under chloride concentration 1, 200, and
$400 \mathrm{mM}$ was calculated to be $92.2,99.5$, and $93.6 \%$, respectively. The particulate $\mathrm{Hg}$ was undetected in " $\mathrm{Hg}+$

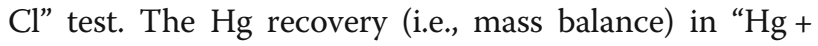
$\mathrm{Cl}$ " tests was calculated to be approximately 100\% (i.e., 95-107\%) (Table 5 and Fig. 6). Overall, the behavior of $\mathrm{Hg}$ adsorption on $\mathrm{AC}$ was nearly the same under the chloride concentration 1-400 mM.

The comparison of calculated $\mathrm{q}_{\mathrm{e}}$ and $\mathrm{THg}$ removal efficiency between additional chloride concentration 0 $400 \mathrm{mM}$ is shown in Fig. 7. The THg removal efficiency was similar at the range of 92-95\%. However, there was a significantly difference in calculated $\mathrm{q}_{\mathrm{e}}$. The $\mathrm{q}_{\mathrm{e}}$ was 6.9, $13.8,16.1$, and $14.2 \mathrm{\mu g} \mathrm{g}^{-1}$ under the chloride concentration $0,1,200$, and $400 \mathrm{mM}$, respectively. The reason may be an escape of $\mathrm{Hg}$ into the air in the absence of chloride. Therefore, the $\mathrm{THg}$ removal includes two mechanisms, $\mathrm{Hg}$ adsorbed in $\mathrm{AC}$ and $\mathrm{Hg}$ escaped to the gas phase in the absence of chloride. Practically, the increase in chloride concentration increased $\mathrm{q}_{\mathrm{e}}$ due to the inhibition of $\mathrm{Hg}$ escape to the gas phase.

Past researches reported that the additional chloride decreased the $\mathrm{Hg}$ adsorption by $\mathrm{AC}$ or other relative adsorbents (Table S4). They suggested that $\mathrm{Hg}-\mathrm{Cl}$ complex was a stable form and poorly adsorbed. Conversely, the presence of chloride could increase $\mathrm{q}_{\mathrm{e}}$ in this study, which contradicted to previous studies. The reason might be the initial $\mathrm{Hg}$ concentrations in these studies were significantly different. The initial $\mathrm{Hg}$ concentration of previous studies was at the range of $10-50 \mathrm{mg} \mathrm{L}^{-1}$; however, the $\mathrm{Hg}$ concentration was approximately $20 \mu \mathrm{g} \mathrm{L}^{-1}$ in this study. Therefore, the inhibition of $\mathrm{Hg}$ adsorption by chloride was 
Table $5 \mathrm{Hg}$ distribution under different chloride concentration

\begin{tabular}{llll}
\hline & \multicolumn{4}{l}{ Initial experimental parameters } \\
Chloride conc. (mM) & 1 & 200 & 400 \\
$\mathrm{Hg}$ conc. $\left(\mu \mathrm{g} \mathrm{L}^{-1}\right)$ & 14.3 & 16.2 & 15.2 \\
$\mathrm{pH}$ & 6.82 & 6.86 & 6.82 \\
Dissolved $\mathrm{O}_{2}\left(\mathrm{mg} \mathrm{L}^{-1}\right)$ & 3.97 & 3.83 & 4.40 \\
& $\mathrm{Hg}$ partition after reaching equilibrium \\
Dissolved $\mathrm{Hg}(\%)$ & 2.7 & 7.9 & 4.8 \\
Hg in AC (\%) & 92.2 & 99.5 & 93.6 \\
Particulate $\mathrm{Hg}(\%)$ & 0.02 & nd & nd \\
\hline
\end{tabular}

The liquid volume: $50 \mathrm{~mL}$; $\mathrm{AC}$ dosage: $50 \mathrm{mg}$; shaking speed: $125 \mathrm{rpm}$; temperature: $30^{\circ} \mathrm{C}$; contact time: $24 \mathrm{~h}$

not obvious in our results. The second possible reason could be an overestimate of $\mathrm{q}_{\mathrm{e}}$ in the previous studies. There was a doubt of $\mathrm{Hg}$ escaping into the air in the absence of chloride or in high $\mathrm{pH}$ condition [43]. Nevertheless, the calculation method of $\mathrm{q}_{\mathrm{e}}$ was typically based on the difference in initial and residual $\mathrm{Hg}$ concentrations in previous studies. Additionally, the $\mathrm{Hg}$ recovery test was not conducted in these relative studies. Therefore, overestimated $q_{e}$ probably occurred in previous studies.

\section{"Hg + sulfide" condition}

The "Hg + sulfide" test was carried out by $\mathrm{Hg}$ adsorption on $\mathrm{AC}$ under sulfide concentrations of 2,10 , and $20 \mu \mathrm{M}$. Table 6 describes the experimental parameters and the results of $\mathrm{Hg}$ distribution. The proportion of "dissolved
$\mathrm{Hg}$ " under sulfide concentration 2, 10, and $20 \mu \mathrm{M}$ was $25.2,35.1$, and $25.0 \%$, respectively; the proportion of " $\mathrm{Hg}$ in $\mathrm{AC}$ " was 28.7, 33.1, and 28.1\%, respectively; and the proportion of "particulate $\mathrm{Hg}$ " was 28.7, 26.8, and 23.6\%, respectively (Fig. 8).

Sulfide has a strong affinity for $\mathrm{Hg}$ tending to form $\mathrm{Hg}$ $\mathrm{S}$ (Eq. (6)) [23]. During an aging process, Hg-S aggregated into large particulate form of $\mathrm{HgS}[21,26,46]$. Through $24 \mathrm{~h}$ contacting with sulfide, there was an amount of $\mathrm{Hg}$ forming into particles $(>0.2 \mu \mathrm{m})$ in this study. The initial $\mathrm{Hg}$ concentration was around $20 \mu \mathrm{g} \mathrm{L}^{-1}(0.1 \mu \mathrm{M})$; however, sulfide concentrations $(2,10$, and $20 \mu \mathrm{M})$ were at least 20 times higher than $\mathrm{Hg}$ concentration. Therefore, sulfide concentration was greatly in excess than the stoichiometric value based on Eqs. (6) and (7). Consequently, a certain proportion of particulate $\mathrm{Hg}$ would be formed. The $\mathrm{Hg}$ recovery was around $80 \%$ in " $\mathrm{Hg}+\mathrm{S}$ " condition, which may be partly due to experimental error because the sample of $5 \mathrm{~mL}$ was firstly taken for measuring "dissolved $\mathrm{Hg}$ " that may cause particulate $\mathrm{Hg}$ loss.

$$
\begin{aligned}
& \mathrm{Hg}^{2+}+H S^{-} \leftrightarrow H g S_{(a q)}^{0}+H^{+} K=10^{26.5} \\
& \mathrm{Hg}^{2+}+H S^{-} \leftrightarrow H g S H^{+} \mathrm{K}=10^{30.2}
\end{aligned}
$$

Around $30 \%$ of $\mathrm{Hg}$ was adsorbed on $\mathrm{AC}$ under different sulfide concentrations. A portion of $\mathrm{Hg}$ was formed as $\mathrm{HgSH}^{+}$in "Hg $+\mathrm{S}$ " (Eq. (7)). The surface charge of AC was negative in this condition (Fig. 3). Therefore, the $\mathrm{Hg}$ species tended to be adsorbed on AC by Van der

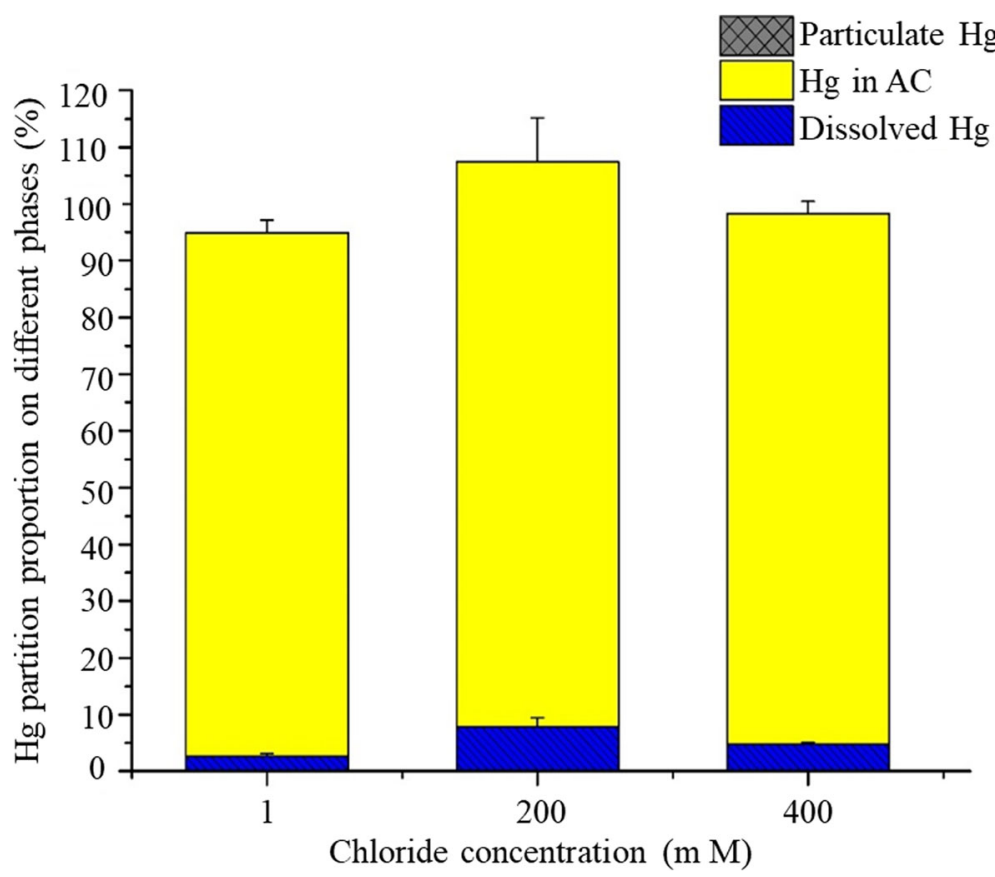

Fig. $6 \mathrm{Hg}$ partition proportion on different phases under different chloride concentration 


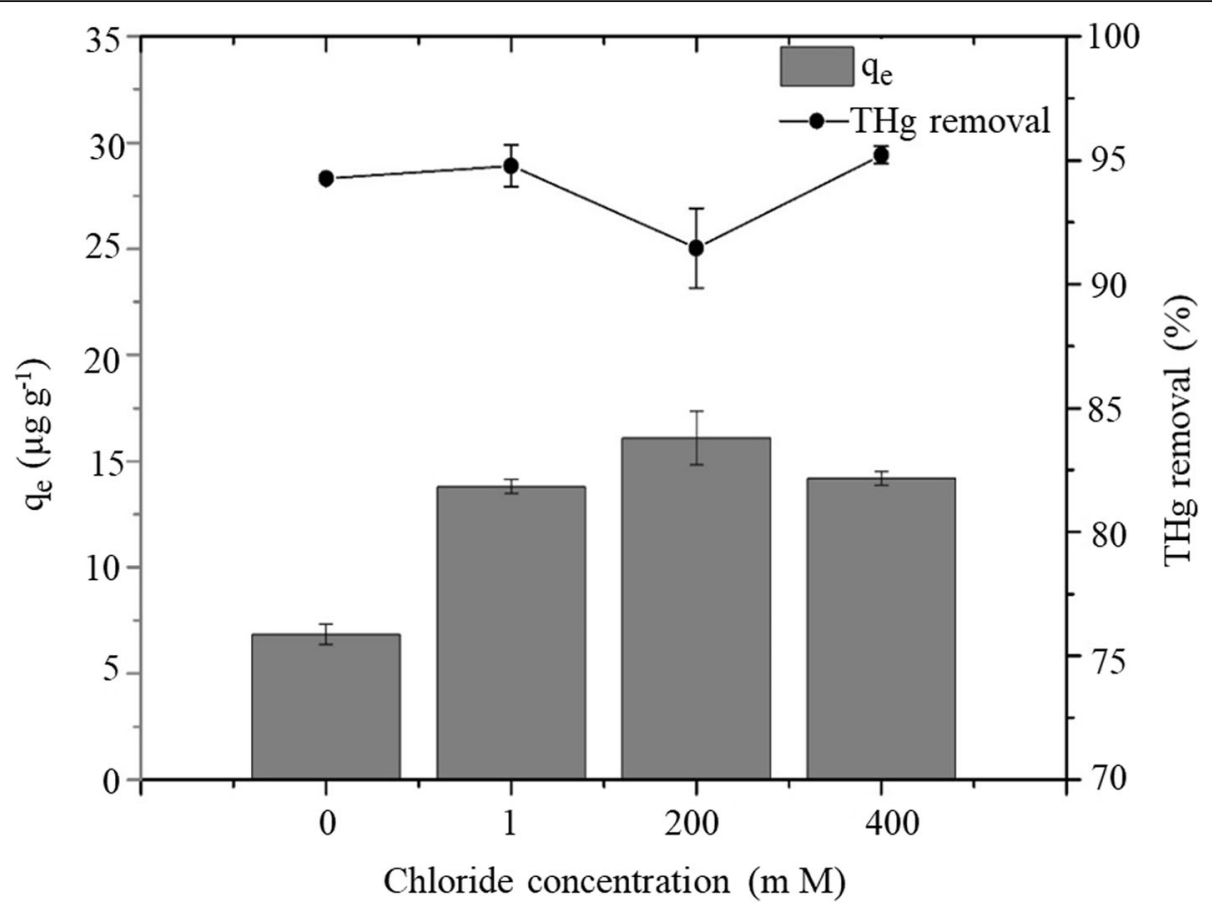

Fig. 7 The THg removal efficiency and the calculated $q_{e}$ under various chloride concentration

Wall's force. Moreover, data from " $\mathrm{Hg}+\mathrm{S}$ " test can be well fitted to the pseudo-second order model. There were two possible mechanisms to remove $\mathrm{Hg}$. One of the mechanisms was chemical precipitation by $\mathrm{Hg}$ bonded to sulfide to form $\mathrm{HgS}_{(\mathrm{s})}$. The other was adsorption of $\mathrm{HgSH}$ ${ }^{+}$by AC. Furthermore, a portion of $\mathrm{Hg}$ might exist in the form of $\mathrm{HgS}_{(\mathrm{aq})}$ which was poorly adsorbed by AC. Therefore, the proportion of "dissolved $\mathrm{Hg}$ " in " $\mathrm{Hg}+\mathrm{S}$ " (around $25 \%)$ was higher than in " $\mathrm{Hg}+\mathrm{Cl}$ " (around 5\%).

\section{"Hg + DOM" condition}

The "Hg + DOM" test was carried out by Hg adsorption on $\mathrm{AC}$ under various DOM concentration within $0.25-20$ $\mathrm{mg} \mathrm{C} \mathrm{L}{ }^{-1}$. Table 7 describes the experimental parameters and the results of $\mathrm{Hg}$ distribution. The proportion of

Table $6 \mathrm{Hg}$ distribution under different sulfide concentration

\begin{tabular}{llll}
\hline & \multicolumn{4}{l}{ Initial experimental parameters } \\
Sulfide conc. $(\mu \mathrm{M})$ & 2 & 10 & 20 \\
$\mathrm{Hg}$ conc. $\left(\mu \mathrm{g} \mathrm{L}^{-1}\right)$ & 16.61 & 17.53 & 18.60 \\
$\mathrm{pH}$ & 6.83 & 7.43 & 6.96 \\
Dissolved $\mathrm{O}_{2}\left(\mathrm{mg} \mathrm{L}^{-1}\right)$ & 3.99 & 3.30 & 4.22 \\
& $\mathrm{Hg}$ partition after reaching equilibrium \\
Dissolved $\mathrm{Hg}(\%)$ & 25.2 & 35.1 & 25.0 \\
Hg in AC (\%) & 28.7 & 33.1 & 28.1 \\
Particulate $\mathrm{Hg}(\%)$ & 28.7 & 26.8 & 23.6 \\
\hline
\end{tabular}

The liquid volume: $50 \mathrm{~mL}$; AC dosage: $50 \mathrm{mg}$; shaking speed: $125 \mathrm{rpm}$; temperature: $30^{\circ} \mathrm{C}$; contact time: $24 \mathrm{~h}$ "dissolved Hg" under DOM concentration 0.25, 0.5, 2,10, and $20 \mathrm{mg}-\mathrm{C} \mathrm{L}^{-1}$ was $45.1,57.8,61.4,68.4$, and $75.7 \%$ respectively; the proportion of " $\mathrm{Hg}$ in $\mathrm{AC}$ " was $61.5,49.3$, $49.1,26.9$, and $14.7 \%$ respectively; and the proportion of "particulate $\mathrm{Hg}$ " was $3.1,4.6,3.2,2.5$, and $2.1 \%$ respectively.

Figure 9 further shows that increasing DOM concentration resulted in more dissolved phase of $\mathrm{Hg}$ in the solution. The proportion of "dissolved Hg" increased 30.6\% from DOM concentration 0.25 to $20 \mathrm{mg} \mathrm{C} \mathrm{L}^{-1}$. This result was also reflected in " $\mathrm{Hg}$ in $\mathrm{AC}$ ". The proportion of "Hg in AC" decreased by $46.8 \%$ from DOM concentration 0.25 to $20 \mathrm{mg} \mathrm{C} \mathrm{L}^{-1}$. The reason for inhibition of $\mathrm{Hg}$ adsorption may be due to the affinity of DOM for $\mathrm{Hg}$. The elemental compositions of SRHA are listed in Table S5. Graham et al. [47] reported that the reduced sulfur in SRHA is about $18.3 \mathrm{~mol} \%$ of total sulfur. Therefore, the ratio of $\mathrm{C}$ to reduced sulfur is $542(\mathrm{w} / \mathrm{w})$. Xia et al. [48] reported that reduced $\mathrm{S}$ in SRHA analyzed by XANES was in the form of thiol/sulfide and thiophene. The thiol functional group on DOM was the major binding site with $\mathrm{Hg}$ [27, 28]. Among the ligands, sulfur-containing ligands bind $\mathrm{Hg}$ much more strongly than oxygen-containing ligands, which appear in AC [28]. Therefore, the phenomenon of $\mathrm{Hg}$ escaping is not apparent and the recovery of $\mathrm{Hg}$ is approximately $100 \%$ (Fig. 9). In addition to thiol functional group, DOM also contained carboxyl (about 9 meq g $^{-1} \mathrm{C}$ ) and phenolic (about $4 \mathrm{meqg}^{-1} \mathrm{C}$ ) functional groups, which are effective binding sites for $\mathrm{Hg}$ 


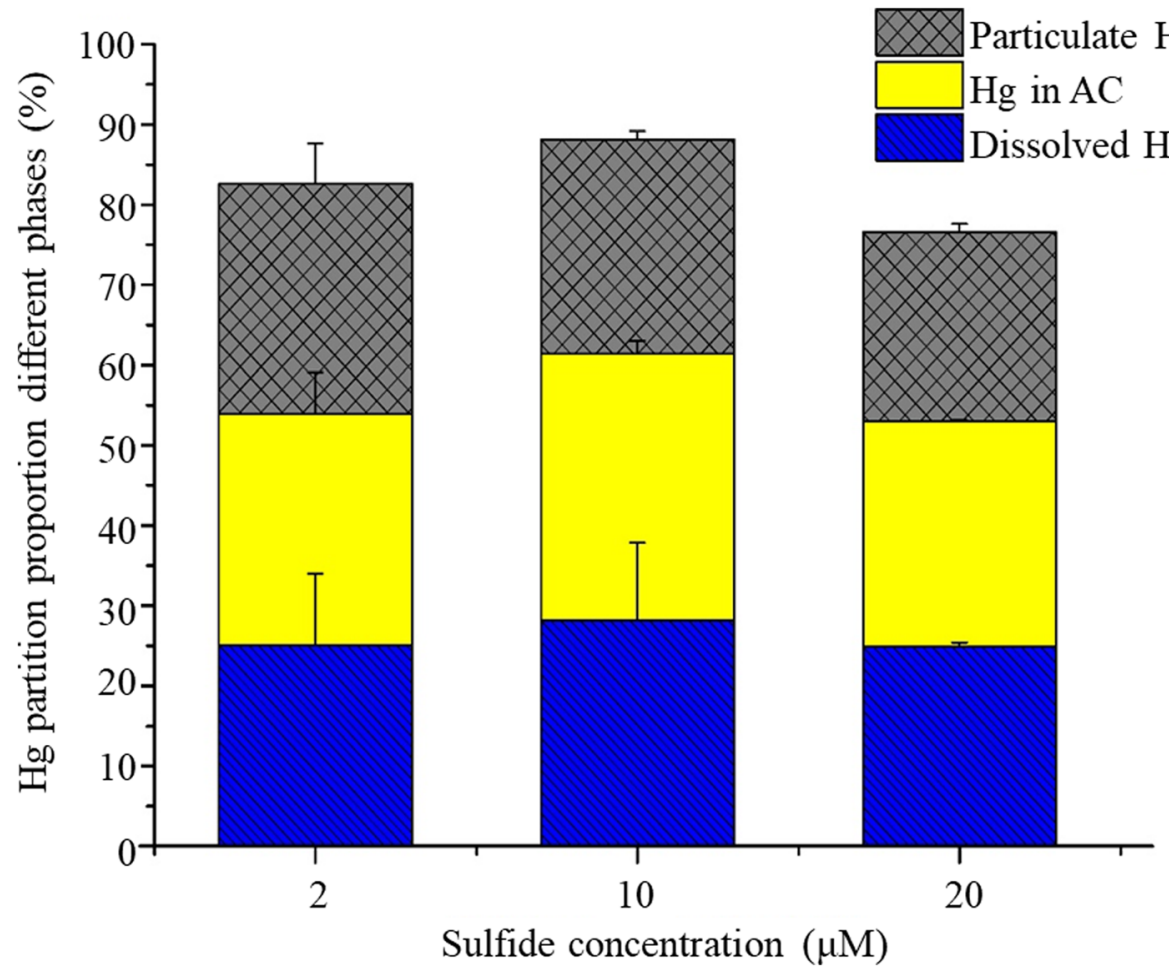

Fig. $8 \mathrm{Hg}$ partition proportion on different phases under different sulfide concentration

$[33,34]$. Hence, DOM is a large molecule tending to bind to $\mathrm{Hg}$. This kind of molecule (DOM-Hg) then separated $\mathrm{Hg}$ from adsorption on AC. Since AC is usually nonpolar or slightly polar, DOM was considered as a stabilization agent for $\mathrm{Hg}$ instead of a carrier for $\mathrm{Hg}$ adsorption onto AC. Therefore, the DOM increased concentration may inhibit $\mathrm{Hg}$ adsorption dramatically.

In addition to DOM stabilizing $\mathrm{Hg}$ in dissolved phase, the formation of $\beta$ - $\mathrm{HgS}$ particles from $\mathrm{Hg}^{2}+$ interacting with DOM was found in others $[49,50]$. The particle size of $\beta-\mathrm{HgS}$ nanoparticles was around $3-5 \mathrm{~nm}$ reported by Manceau et al. [50]. Therefore, $\beta-\mathrm{HgS}$ nanoparticles

Table $7 \mathrm{Hg}$ distribution under different DOM concentration

\begin{tabular}{llllll}
\hline \multicolumn{5}{c}{ Initial experimental parameters } \\
DOM conc. (mg C L & & \\
Hg conc. $\left(\mu \mathrm{g} \mathrm{L}^{-1}\right)$ & 0.25 & 0.5 & 2 & 10 & 20 \\
$\mathrm{pH}$ & 18.0 & 12.4 & 12.1 & 13.9 & 15.9 \\
Dissolved $\mathrm{O}_{2}\left(\mathrm{mg} \mathrm{L}^{-1}\right)$ & 4.33 & 3.71 & 3.65 & 3.67 & 3.13 \\
& 6.73 & 6.94 & 6.87 & 6.86 & 6.94 \\
Dissolved $\mathrm{Hg}(\%)$ & 45.1 & 57.8 & 61.4 & 68.4 & 75.7 \\
Hg in AC (\%) & 61.5 & 49.3 & 49.1 & 26.9 & 14.7 \\
Particulate $\mathrm{Hg}(\%)$ & 3.1 & 4.6 & 3.2 & 2.5 & 2.1 \\
\hline
\end{tabular}

The liquid volume: $50 \mathrm{~mL}$; $\mathrm{AC}$ dosage: $50 \mathrm{mg}$; shaking speed: $125 \mathrm{rpm}$; temperature: $30^{\circ} \mathrm{C}$; contact time: $24 \mathrm{~h}$ might be formed in this study. If the particle size of $\beta$ $\mathrm{HgS}$ was lower than $0.2 \mu \mathrm{m}$, it would be classified into "dissolved $\mathrm{Hg}$ " in this study. The formation of $\beta-\mathrm{HgS}$ nanoparticles was also a reason for increasing the proportion of "dissolved $\mathrm{Hg}$ ". However, $\beta$ - HgS nanoparticles had the ability of aggregation. Therefore, even with the presence of DOM, $\beta-\mathrm{HgS}$ particles $(>0.2 \mu \mathrm{m})$ might still be formed during the adsorption process with a 24-h duration. For here, $2.1-4.6 \%$ of $\mathrm{Hg}$ particles were formed in "Hg + DOM". This result showed that DOM could inhibit $\beta$-HgS aggregation significantly in this study.

\section{Conclusions}

The main aim of this study is to better understand the influences of chloride, sulfide, and DOM concentrations on the $\mathrm{Hg}$ adsorption equilibrium and kinetics of $\mathrm{AC}$ in an aqueous system. The important findings in this study are concluded as follows:

1. The rate of $\mathrm{Hg}$ adsorption on $\mathrm{AC}$ varied with the presence of sulfide, chloride, and DOM, from fast to slow. $\mathrm{Hg}$ adsorption might be directly bonded on $\mathrm{AC}$ with $\mathrm{Hg}-\mathrm{Cl}$ and $\mathrm{Hg}-\mathrm{DOM}$ complexes. The $\mathrm{Hg}$ adsorption kinetics by $\mathrm{AC}$ in " $\mathrm{Hg}+\mathrm{Cl}$ " and " $\mathrm{Hg}+$ DOM" conditions are mainly controlled by intraparticle diffusion. Data from "Hg $+\mathrm{S}$ " test were better fitted to pseudo-second order model, resulting from 


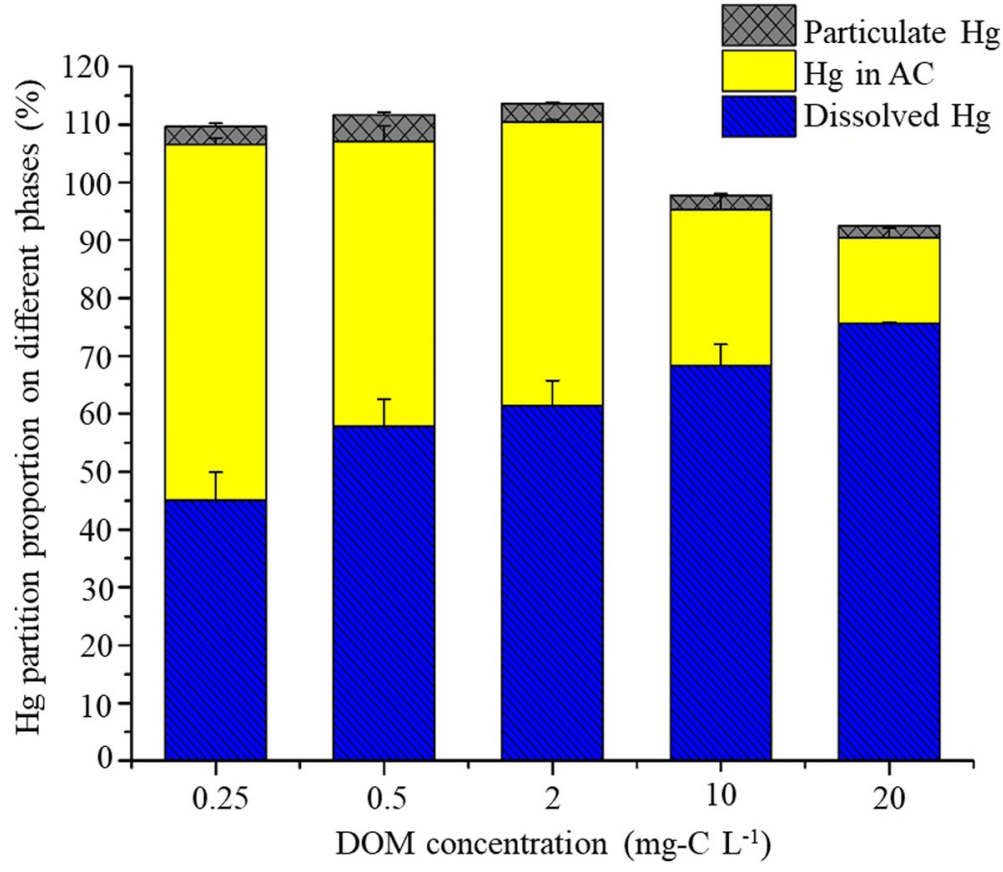

Fig. $9 \mathrm{Hg}$ partition proportion on different phases under different DOM concentration

$\mathrm{Hg}$ adsorption into $\mathrm{AC}$ and chemisorption of sulfide and $\mathrm{Hg}$.

2. There were various levels of $\mathrm{Hg}$ escaping into the air in the absence of chloride in this study.

Therefore, the investigation of $\mathrm{Hg}$ distribution is necessary to ensure the accuracy of calculated equilibrium capacity $\left(\mathrm{q}_{\mathrm{e}}\right)$ by mass balance, which could be overestimated by several earlier studies.

3. The THg removal efficiency (92-95\%) was similar in the absence and the presence of chloride (1-400 $\mathrm{mM})$. The increase in chloride concentration practically increased the $\mathrm{q}_{\mathrm{e}}$ due to inhibition of $\mathrm{Hg}$ escape in this study. This result was different with those of previous studies, which may due to the significant difference in initial $\mathrm{Hg}$ concentration and the overestimated $\mathrm{q}_{\mathrm{e}}$ in past studies.

4. The THg removal efficiency was around $65-75 \%$ in "Hg + sulfide" test. Among the removed Hg, there were $24-29 \%$ of $\mathrm{Hg}$ forming into particles and around $30 \%$ of $\mathrm{Hg}$ adsorbed on $\mathrm{AC}$ under sulfide concentration $(2-20 \mu \mathrm{M})$. Hg of $25-35 \%$ might exist in the form of $\mathrm{HgS}_{(\mathrm{aq})}$ which was hardly adsorbed by AC.

5. Increasing DOM concentration led to more dissolved phase of $\mathrm{Hg}$ in " $\mathrm{Hg}+\mathrm{DOM}$ " condition. The proportion of "dissolved $\mathrm{Hg}$ " increased 31\% from DOM concentration 0.25 to $20 \mathrm{mg} \mathrm{C} \mathrm{L}^{-1}$. Simultaneously, the proportion of " $\mathrm{Hg}$ in $\mathrm{AC}$ " decreased 47\%. Thiol groups on DOM binding with
$\mathrm{Hg}$ could separate $\mathrm{Hg}$ from the adsorption phase of $\mathrm{AC}$ and stabilize $\mathrm{Hg}$ in the dissolved phase.

6. Overall, the presence of $\mathrm{Cl}^{-}$increased the $\mathrm{Hg}$ adsorption on AC. It is a positive effect for AC application in thin layer capping. However, sulfide and DOM significantly decreased $\mathrm{q}_{\mathrm{e}}$ due to the formation of $\mathrm{Hg}-\mathrm{S}$ and $\mathrm{Hg}$-DOM. In particular, the negative effect of DOM should be overcome in future application.

\section{Supplementary information}

Supplementary information accompanies this paper at https://doi.org/10. 1186/s42834-020-00065-5.

Additional file 1.

\section{Acknowledgements}

This work was financially supported by the Environmental Protection Administration, Taiwan under Grant no. 107c000734. The opinions expressed in this paper are not necessarily those of the sponsor.

\section{Authors' contributions}

Conceptualization, C.C., Y.T., and H.C.H.; methodology, C.C., Y.T., and B.L.C.; formal analysis, C.C.; investigation, C.C.; data curation, C.C.; writing - original draft preparation, C.C. and H.C.H.; writing-review and editing, H.C.H.; visualization, C.C.; funding acquisition, H.C.H. All authors read and approved the final manuscript.

\section{Funding}

This work was financially supported by the Environmental Protection Administration, Taiwan under Grant no. 107c000734. 


\section{Availability of data and materials}

All data generated or analyzed during this study are included in this published article and its supplementary information files.

\section{Competing interests}

The authors declare they have no competing interests.

Received: 14 June 2020 Accepted: 11 September 2020 Published online: 29 September 2020

\section{References}

1. Hong YS, Kim YM, Lee KE. Methylmercury exposure and health effects. J Prev Med Public Health. 2012;45:353-63.

2. Carocci A, Rovito N, Sinicropi MS, Genchi G. Mercury toxicity and neurodegenerative effects. In: Whitacre DM, editor. Reviews of environmental contamination and toxicology. Volume 229. Cham: Springer; 2014. p. 1-18

3. Bailey LT, Mitchell CPJ, Engstrom DR, Berndt ME, Wasik JKC, Johnson NW. Influence of porewater sulfide on methylmercury production and partitioning in sulfate-impacted lake sediments. Sci Total Environ. 2017;580: 1197-204.

4. UNEP. Global Mercury Assessment 2013: Sources, Emissions, Releases and Environmental Transport. Geneva: UNEP Chemicals Branch; 2013.

5. Gilmour CC, Podar M, Bullock AL, Graham AM, Brown SD, Somenahally AC, et al. Mercury methylation by novel microorganisms from new environments. Environ Sci Technol. 2013;47:11810-20.

6. Wang YL, Fang MD, Chien LC, Lin CC, Hsi HC. Distribution of mercury and methylmercury in surface water and surface sediment of river, irrigation canal, reservoir, and wetland in Taiwan. Environ Sci Pollut R. 2019;26:1776273.

7. Ghosh U, Luthy RG, Cornelissen G, Werner D, Menzie CA. In-situ sorbent amendments: a new direction in contaminated sediment management. Environ Sci Technol. 2011;45:1163-8.

8. Randall PM, Chattopadhyay S. Mercury contaminated sediment sites - an evaluation of remedial options. Environ Res. 2013;125:131-49.

9. Rudd J, Harris R, Sellers P. Advice on Mercury Remediation Options for the Wabigoon-English River System. 2016.

10. Kupryianchyk D, Rakowska MI, Reible D, Harmsen J, Cornelissen G, van Veggel $M$, et al. Positioning activated carbon amendment technologies in a novel framework for sediment management. Integr Environ Asses. 2015;11: 221-34.

11. Martins M, Costa PM, Raimundo J, Vale C, Ferreira AM, Costa MH. Impact of remobilized contaminants in Mytilus edulis during dredging operations in a harbour area: bioaccumulation and biomarker responses. Ecotox Environ Safe. 2012;85:96-103.

12. Zhang C, Zhu MY, Zeng GM, Yu ZG, Cui F, Yang ZZ, et al. Active capping technology: a new environmental remediation of contaminated sediment. Environ Sci Pollut R. 2016;23:4370-86.

13. Ting $Y$, Chen C, Ch'ng BL, Wang YL, Hsi HC. Using raw and sulfurimpregnated activated carbon as active cap for leaching inhibition of mercury and methylmercury from contaminated sediment. J Hazard Mater 2018;354:116-24

14. Ting $Y$, Hsi HC. Iron sulfide minerals as potential active capping materials for mercury-contaminated sediment remediation: a minireview. SustainabilityBasel. 2019;11:1747.

15. Saha B, Tai MH, Streat M. Study of activated carbon after oxidation and subsequent treatment characterization. Process Saf Environ. 2001;79:211-7.

16. Lu XC, Jiang JC, Sun K, Xie XP, Hu YM. Surface modification, characterization and adsorptive properties of a coconut activated carbon. Appl Surf Sci. 2012;258:8247-52

17. Lu XC, Jiang JC, Sun K, Wang JB, Zhang YP. Influence of the pore structure and surface chemical properties of activated carbon on the adsorption of mercury from aqueous solutions. Mar Pollut Bull. 2014;78:69-76.

18. Hsu CJ, Chiou HJ, Chen YH, Lin KS, Rood MJ, Hsi HC. Mercury adsorption and re-emission inhibition from actual WFGD wastewater using sulfurcontaining activated carbon. Environ Res. 2019;168:319-28.

19. Hsu CJ, Chen $\mathrm{YH}, \mathrm{Hsi} \mathrm{HC}$. Adsorption of aqueous $\mathrm{Hg}^{2+}$ and inhibition of $\mathrm{Hg}^{\mathrm{O}}$ re-emission from actual seawater flue gas desulfurization wastewater by using sulfurized activated carbon and $\mathrm{NaClO}$. Sci Total Environ. 2020;711: 135172 .
20. Rickards D, Mussmann M, Steadman JA. Sedimentary sulfides. Elements. 2017;13:117-22.

21. Mazrui NM, Jonsson S, Thota S, Zhao J, Mason RP. Enhanced availability of mercury bound to dissolved organic matter for methylation in marine sediments. Geochim Cosmochim Ac. 2016;194:153-62.

22. Jonsson S, Skyllberg U, Nilsson MB, Westlund PO, Shchukarev A, Lundberg E, et al. Mercury methylation rates for geochemically relevant $\mathrm{HG}^{\text {"l }}$ species in sediments. Environ Sci Technol. 2012;46:11653-9.

23. Benoit JM, Mason RP, Gilmour CC. Estimation of mercury-sulfide speciation in sediment pore waters using octanol-water partitioning and implications for availability to methylating bacteria. Environ Toxicol Chem. 1999;18:213841.

24. Deonarine A, Hsu-Kim H. Precipitation of mercuric sulfide nanoparticles in NOM-containing water: implications for the natural environment. Environ Sci Technol. 2009:43:2368-73.

25. Findlay SEG, Parr TB. Dissolved organic matter. In: Lamberti GA, Hauer FR, editors. Methods in stream ecology. 3rd ed. Volume 2: ecosystem function. London: Academic Press; 2017. p. 21-36.

26. Mazrui NM, Seelen E, King'ondu CK, Thota S, Awino J, Rouge J, et al. The precipitation, growth and stability of mercury sulfide nanoparticles formed in the presence of marine dissolved organic matter. Environ Sci-Proc Imp. 2018;20:642-56.

27. Song Y, Jiang T, Liem-Nguyen V, Sparrman T, Bjorn E, Skyllberg U. Thermodynamics of $\mathrm{Hg}$ (II) bonding to thiol groups in Suwannee River natural organic matter resolved by competitive ligand exchange, $\mathrm{Hg} \mathrm{L}_{1 I^{-}}$ edge EXAFS and 'H NMR spectroscopy. Environ Sci Technol. 2018;52:8292301.

28. Ravichandran M. Interactions between mercury and dissolved organic matter - a review. Chemosphere. 2004;55:319-31.

29. Lee $\mathrm{S}$, Roh Y, Kim KW. Influence of chloride ions on the reduction of mercury species in the presence of dissolved organic matter. Environ Geochem HIth. 2019:41:71-9.

30. Hsi HC, Rood MJ, Rostam-Abadi M, Chen SG, Chang R. Effects of sulfu impregnation temperature on the properties and mercury adsorption capacities of activated carbon fibers (ACFs). Environ Sci Technol. 2001;35: 2785-91.

31. Martinez MT, Callejas MA, Benito AM, Cochet M, Seeger T, Anson A, et al. Sensitivity of single wall carbon nanotubes to oxidative processing: structural modification, intercalation and functionalisation. Carbon. 2003;41: 2247-56.

32. Oh YJ, Yoo JJ, Kim Yl, Yoon JK, Yoon HN, Kim JH, et al. Oxygen functional groups and electrochemical capacitive behavior of incompletely reduced graphene oxides as a thin-film electrode of supercapacitor. Electrochim Acta. 2014;116:118-28.

33. Faheem, Bao JG, Zheng H, Tufail H, Irshad S, Du JK. Adsorption-assisted decontamination of $\mathrm{Hg}$ (II) from aqueous solution by multi-functionalized corncob-derived biochar. RSC Adv. 2018:8:38425-35.

34. Dong XL, Ma LNQ, Zhu YJ, Li YC, Gu BH. Mechanistic investigation of mercury sorption by Brazilian pepper biochars of different pyrolytic temperatures based on X-ray photoelectron spectroscopy and flow calorimetry. Environ Sci Technol. 2013:47:12156-64.

35. Li YH, Lee CW, Gullett BK. Importance of activated carbon's oxygen surface functional groups on elemental mercury adsorption. Fuel. 2003;82:451-7.

36. Singh J, Huang PM, Hammer UT, Liaw WK. Influence of citric acid and glycine on the adsorption of mercury (II) by kaolinite under various $\mathrm{pH}$ conditions. Clay Clay Miner. 1996;44:41-8.

37. Ho YS, McKay G. Pseudo-second order model for sorption processes. Process Biochem. 1999;34:451-65.

38. Poulin BA, Gerbig CA, Kim CS, Stegemeier JP, Ryan JN, Aiken GR. Effects of sulfide concentration and dissolved organic matter characteristics on the structure of nanocolloidal metacinnabar. Environ Sci Technol. 2017;51: 13133-42.

39. Aiken GR, Hsu-Kim H, Ryan JN. Influence of dissolved organic matter on the environmental fate of metals, nanoparticles, and colloids. Environ Sci Technol. 2011:45:3196-201.

40. Asasian N, Kaghazchi T, Soleimani M. Elimination of mercury by adsorption onto activated carbon prepared from the biomass material. J Ind Eng Chem. 2012;18:283-9.

41. Boutsika LG, Karapanagioti HK, Manariotis ID. Effect of chloride and nitrate salts on $\mathrm{Hg}$ (II) sorption by raw and pyrolyzed malt spent rootlets. J Chem Technol Biot. 2017;92:1912-8. 
42. Robles I, Bustos E, Lakatos J. Adsorption study of mercury on lignite in the presence of different anions. Sustain Environ Res. 2016;26:136-41.

43. Chen CM, Liu ST, Gao Y, Liu YC. Investigation on mercury reemission from limestone-gypsum wet flue gas desulfurization slurry. Sci World J. 2014;2014: 581724.

44. Ranganathan $\mathrm{K}$. Adsorption of $\mathrm{Hg}$ (II) ions from aqueous chloride solutions using powdered activated carbons. Carbon. 2003;41:1087-92.

45. Namasivayam C, Kadirvelu K. Uptake of mercury (II) from wastewater by activated carbon from an unwanted agricultural solid by-product: coirpith. Carbon. 1999;37:79-84.

46. Pham ALT, Morris A, Zhang T, Ticknor J, Levard C, Hsu-Kim H. Precipitation of nanoscale mercuric sulfides in the presence of natural organic matter: structural properties, aggregation, and biotransformation. Geochim Cosmochim Ac. 2014;133:204-15.

47. Graham AM, Aiken GR, Gilmour CC. Dissolved organic matter enhances microbial mercury methylation under sulfidic conditions. Environ Sci Technol. 2012;46:2715-23.

48. Xia K, Weesner F, Bleam WF, Bloom PR, Skyllberg UL, Helmke PA. XANES studies of oxidation states of sulfur in aquatic and soil humic substances. Soil Sci Soc Am J. 1998;62:1240-6.

49. Luo HW, Yin XP, Jubb AM, Chen HM, Lu X, Zhang WH, et al. Photochemical reactions between mercury $(\mathrm{Hg})$ and dissolved organic matter decrease $\mathrm{Hg}$ bioavailability and methylation. Environ Pollut. 2017;220:1359-65.

50. Manceau A, Lemouchi C, Enescu M, Gaillot AC, Lanson M, Magnin V, et al. Formation of mercury sulfide from $\mathrm{Hg}$ (II)-thiolate complexes in natural organic matter. Environ Sci Technol. 2015;49:9787-96.

\section{Publisher's Note}

Springer Nature remains neutral with regard to jurisdictional claims in published maps and institutional affiliations.

Ready to submit your research? Choose BMC and benefit from:

- fast, convenient online submission

- thorough peer review by experienced researchers in your field

- rapid publication on acceptance

- support for research data, including large and complex data types

- gold Open Access which fosters wider collaboration and increased citations

- maximum visibility for your research: over $100 \mathrm{M}$ website views per year

At $\mathrm{BMC}$, research is always in progress.

Learn more biomedcentral.com/submissions 